\title{
WestVirginiaUniversity
}

THE RESEARCH REPOSITORY @ WVU

Graduate Theses, Dissertations, and Problem Reports

1999

\section{Concert waltzes for solo piano}

Kyung-Ae Kim

West Virginia University

Follow this and additional works at: https://researchrepository.wvu.edu/etd

\section{Recommended Citation}

Kim, Kyung-Ae, "Concert waltzes for solo piano" (1999). Graduate Theses, Dissertations, and Problem Reports. 3165.

https://researchrepository.wvu.edu/etd/3165

This Dissertation is protected by copyright and/or related rights. It has been brought to you by the The Research Repository @ WVU with permission from the rights-holder(s). You are free to use this Dissertation in any way that is permitted by the copyright and related rights legislation that applies to your use. For other uses you must obtain permission from the rights-holder(s) directly, unless additional rights are indicated by a Creative Commons license in the record and/ or on the work itself. This Dissertation has been accepted for inclusion in WVU Graduate Theses, Dissertations, and Problem Reports collection by an authorized administrator of The Research Repository @ WVU.

For more information, please contact researchrepository@mail.wvu.edu. 


\title{
Concert Waltzes for Solo Piano
}

\author{
Kyung-Ae Kim \\ Research Project submitted to the \\ College of Creative Arts \\ at West Virginia University \\ in partial fulfillment of the requirements \\ for the degree of \\ Doctor of Musical Arts
}

Dr. Peter Amstutz, Chair

Dr. Terry Ewell

Dr. James Miltenberger

Dr. Soo Geun Song

Dr. Virginia Thompson

Division of Music

\section{Morgantown, West Virginia \\ 1999}

Keywords: Solo Piano Waltzes, Survey, Development, Comparisons 


\title{
Concert Waltzes for Solo Piano
}

\section{Kyung-Ae Kim}

\begin{abstract}
The waltz is a dance in three-four time for couples. The origin of the waltz is obscure, but it may come from the influence of the Ländler. In the nineteenth century, the waltz was the most popular ballroom dance in Europe, but as dance music the waltz developed into a stylized and refined form in the hands of the major composers.

The purpose of this study is:

1. To examine the development of the waltz as composed for solo piano, in order to understand the characteristic styles of one composer as compared to another and,

2. To survey the various formal structures as they evolved over time during the nineteenth and twentieth centuries.

This research will examine not only the development of the waltz, but will also focus on major composers' styles of writing for solo piano.

I. The Origins of the Waltz

A. The appearance of the waltz in the late eighteenth century

B. Early examples of piano waltzes and their composers

C. The contribution of Johann Strauss Jr. and Joseph Lanner in Vienna

II. The Nineteenth Century

A. Schubert

B. Waltzes by four major composers, (Weber, Chopin, Brahms and Liszt), with brief mention of Schumann, Grieg and other nationalistic composers of the nineteenth century

C. Analysis of Styles: What are the styles and formal structures of these major composer's works?

D. Comparison and Contrast: What can be learned by comparing and contrasting compositional styles in these nineteenth-century works?
\end{abstract}

III. The Twentieth Century

A. Waltzes by Ravel, Bartók, Morton Gould, and other composers, with brief discussion of those by Schönberg and Prokofiev

B. Analysis of Styles: What styles and formal structures do these composers employ?

C. Comparison and Contrast: What can be learned through a comparison and contrast of the waltzes by these composers?

IV. Summary

A. What are the major influences on the composers of the nineteenth century and those of the twentieth century?

B. Contributions of the major composers, as well as comparison and contrast between the nineteenth and the twentieth centuries. 


\section{Table of Contents}

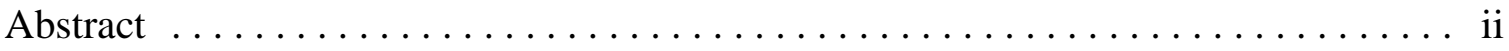

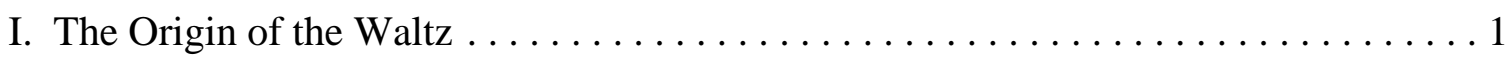

II. Piano Waltzes of The Nineteenth-Century

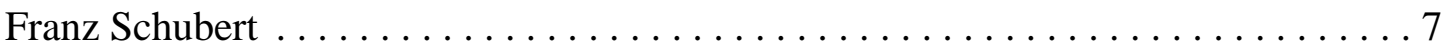

Carl Maria von Weber .................................... 11

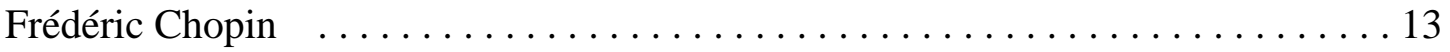

Johannes Brahms . . . . . . . . . . . . . . . . . . . . . . . . . . . . . 19

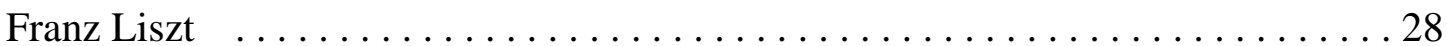

Robert Schumann .................................... 34

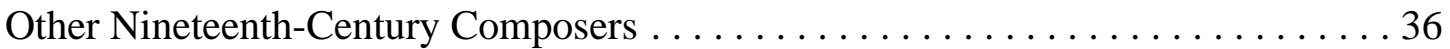

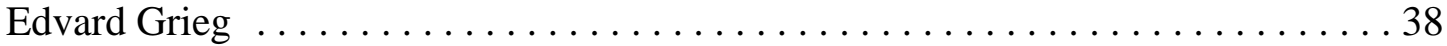

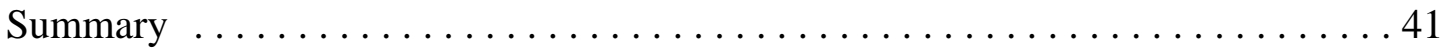

III. Piano Waltzes of The Twentieth-Century

Béla Bartók .......................................44 44

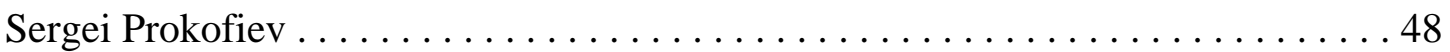

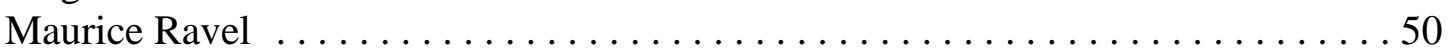

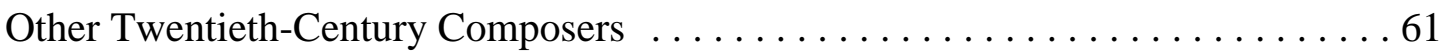

Morton Gould ......................................67

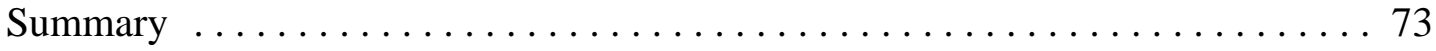

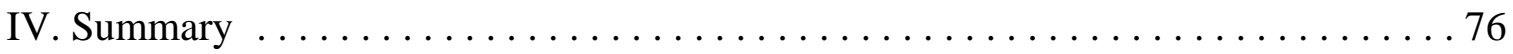

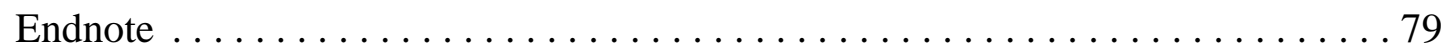

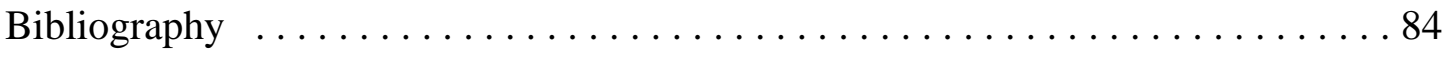




\section{Chapter one}

\section{The Origins of the Waltz}

"The Waltz is generally admitted to be a promoter of vigorous health and productive of an hilarity of spirits"1

English dancing master, Thomas Wilson

The waltz is a dance in three-four time for couples. It was the most popular ballroom dance of the nineteenth century. The name, "waltz," comes from an old German verb, walzen, that means to wander, to roll, to turn or to glide.

The origins of the waltz are obscure, but the late-eighteenth-century dance called Ländler (from Land ob der Enns, a region of northern Austria) is regarded as the true ancestor of the waltz. The Ländler, a dance basic to the folk music of Austria, is a slow, turning Alpine dance in three-four time. In the beginning of the nineteenth century, the terms Deutscher Ländler and Walzer were often used indiscriminately, but the Ländler was usually played more slowly.

The earliest example of music associated with "Walzer" appeared in the musical comedy Der auf das neue begeisterte und belebte Bernardon, written by a famous Viennese clown, Josef Kurz, in 1754. 
Example 1-1. Josef Kurz: Der auf das neue begeisterte und belebte Bernardon, from Act 2
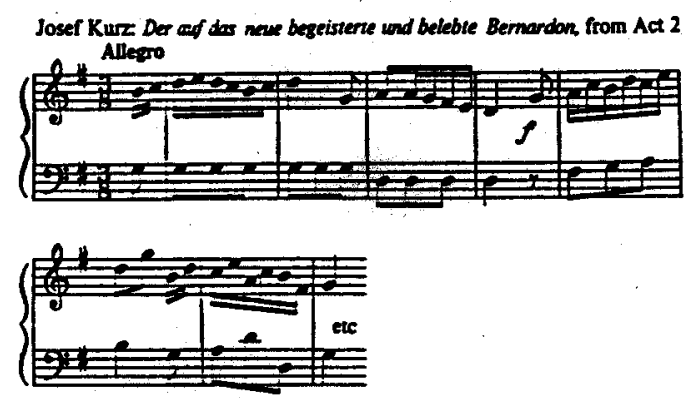

The clown sang the words:

"Bald walzen umadum mit heirassa drum" ("Turn about waltzing and cheer as you turn." $)^{2}$

Another early example of waltz appears in Spanish composer Vincent Martin's opera called Una cosa rara, which was performed in Vienna during 1786. An innovation of Una cosa rara was the insertion of a waltz interlude. According to Gartenberg, ${ }^{3}$ this waltz is regarded as the original model for this opera. Although it had no clear influence on the historical development of the waltz, this interlude became the main attraction of this opera.

According to folklore and confirmed by the musical research of the Austrian musicologists Pommer, Zoder and Kronfuss, many waltz tunes can be traced to simple yodeling melodies. ${ }^{4}$

The increasing popularity of the waltz in the early nineteenth century brought with it resistance and objections in Germany, England and France. There are two main 
reasons for these complaints. First were medical considerations, because of the speed with which the dancers whirled around the room. Second were moral grounds, because the closeness with which the partners held each other brought antagonism. ${ }^{5}$

However, in spite of all these objections, the waltz triumphed in popularity. During the Viennese Congress of 1814-1815, the waltz was danced again and again. ${ }^{6}$ In Vienna, there was no doubting the popularity of waltzing as a pastime. Because of its popularity, the demand for new waltz music increased and eminent musicians were attracted to this genre.

This paper will focus on waltzes written for solo piano. One of the first known piano waltzes appears in a sonatina by Haydn where the customary minuet was replaced by a "mouvement de walze." ${ }^{7}$ Friedrich Heinrich Himmel, Johann Nepomuk Hummel, Anton Diabelli and Carl Czerny wrote other early examples of waltzes for piano.

Friedrich Heinrich Himmel (1765-1814) was known as a composer of songs and operas. In 1840, Himmel wrote Sechs grosse Walzer, Op. 30, a series of six waltzes with interrelation of keys: C major-G major-C major-F major-C major.

Johann Nepomuk Hummel (1778-1837), a renowned pianist, contributed to the development of Viennese waltzes. In 1808, he wrote a series of large works entitled "Tänze für die Apollo Säle," for the opening of a large dance hall, the Apollo Rooms. The style of this work reveals gracefully constructed "German dances" with delicate trios and brilliant codas. As a pianist of great virtuosity, Hummel wrote some bravura passages, but, according to Nettl, this work lacked charming melodies. ${ }^{8}$

Anton Diabelli (1781-1858) was a Viennese music publisher who submitted a 
waltz of his own invention to fifty composers, including Beethoven, to collect a set of variations on it. On this simple waltz by Diabelli, Beethoven produced an enormous set of variations in C major, Op. 120 (1819-1823). ${ }^{9}$

Example 1-2. Waltz by Diabelli

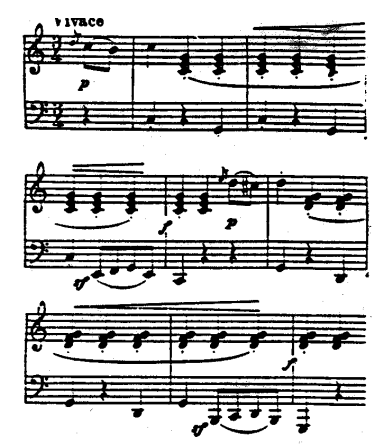

Some of the other waltzes on this tune have also been published, including a contribution by the young Franz Liszt.

Carl Czerny (1791-1857) wrote a set of variations based on Schubert's Trauerwalzer, Op. 9. This work by Czerny was published by Steiner \& Co. of Vienna and it was advertised in the Wiener Zeitung on October 15, 1821. However, Schubert's waltz had been published anonymously at that time; thus, neither Czerny nor his publisher knew that Schubert was the composer. One month later, on November 29, 1821, Schubert's first set of dances (Op. 9, including the Trauerwalzer) was published by Cappi \& Diabelli. This specific waltz became widely popular in Vienna. It was passed on from individual to individual, from group to group, sometimes by transcriptions or by ear, until the whole city knew it. ${ }^{10}$

The two composers whose names become almost synonymous with Viennese waltzes were Joseph Lanner and Johann Strauss (the elder), followed also by Strauss's sons. 
Joseph Lanner (1801-1843) was an Austrian dance composer and violinist. He was the son of a glovemaker and was virtually self-taught in music. At the age of twelve, Lanner became a violinist in a dance orchestra in which Johann Strauss (the elder) was also a young violinist.

Lanner's special talent was a coaxing sort of expression, with delicacy and melodic appeal. It is said that the Viennese expressed the difference between Lanner's and Strauss's music as follows: Lanner's said "Pray, dance! I beg you!" On the other hand, Strauss's said "You must dance, I command you!" Strauss's music demonstrated his fiery rhythmic variety. ${ }^{11}$

Johann Strauss, Senior (1804-1849) was an Austrian composer, conductor, violinist, and founder of the "Strauss Waltz Dynasty." Strauss toured widely in Europe, including Germany in 1843-1846, and France and Britain in 1837-1838. By contrast, Lanner rarely left Vienna. Strauss was appointed Kapellmeister of a Viennese regiment and wrote dance music for the court ball. Strauss composed 251 works of dance music and 152 of these were waltzes. ${ }^{12}$

Lanner and Strauss worked together for years. Although they split up in 1825, there are some common features in their music. First, both were excellent violinists; thus, their waltz melodies often show violinistic character. Second, their performing styles alternated conducting with the bow and joining the orchestra on their instrument. Later this procedure became a tradition in Viennese light music concerts. Third, both Lanner and Strauss expanded waltz form by adding an introduction and a coda. Fourth, they enlarged the orchestration from a small string band to full classical size. Last, both became famous for their waltzes. ${ }^{13}$ 
The most widely popular composer of light waltzes was Johann Strauss, Junior (1825-1899), eldest son of Strauss Senior. The younger Strauss composed nearly 400 waltzes and became known as the "Waltz King." Strauss toured widely, like his father, including the United States and several countries of Europe. In 1855 he was engaged to direct summer concerts in Petropaulovsky Park, St. Petersburg Russia, for ten years. From 1863-1872, Strauss conducted the Austrian court ball. Strauss's brothers Josef and Eduard were also composers of dance music. The three Strauss sons were regarded as the "Waltz Family" and they completely controlled music for the court ball and also for concerts. $^{14}$

Strauss's works showed a fusion of his father's rhythmic variety and Lanner's lyrical style, as revealed, for example, in Accellerationen Op. 234 (1860). However, Strauss's style was more influenced by Lanner's lyrical style than by his own father's. In addition, the formal structure of Strauss's waltzes is slightly more extended than that of his father's and Lanner's later waltzes. The formal structure includes a slow introduction, usually followed by five waltzes and a coda. ${ }^{15}$ 


\section{Chapter Two \\ Piano Waltzes of the Nineteenth-Century}

In the nineteenth century, the waltz extensively invaded instrumental art music. This section of the paper will discuss solo-piano waltzes by five major composers: Schubert, Weber, Chopin, Brahms and Liszt. Also, it will include brief discussion of waltzes by Schumann and Grieg, and a listing of waltzes by other composers of the nineteenth century.

Franz Schubert (1797-1828)

Schubert had a prodigious talent for producing dance music and he wrote more than thirty sets of dances under various titles, including Minuette, Zwölf Wiener Deutsche, Ländler, Deutsche Tänze and Menuette mit Trio. His waltzes are appropriate for actual dancing, perhaps as entertainment in the home. Generally, Schubert's waltzes are short, technically easy and small in form. However, some later waltzes by Schubert make technical demands on the player. ${ }^{16}$ Examples include continuous octaves in the melody part (D. 969, No.12) and chordal playing (D. 969, No.1).

Among Schubert's later works, Zwölf Valses nobles, D. 969, the first waltz starts with the melody in octaves and changes to chords. Thus, we find a relatively thick texture, at a dynamic level of fortissimo. 
Example 2-1. "Zwölf Valses nobles" $\quad$ D. 969, No. 1, mm. 1- 8

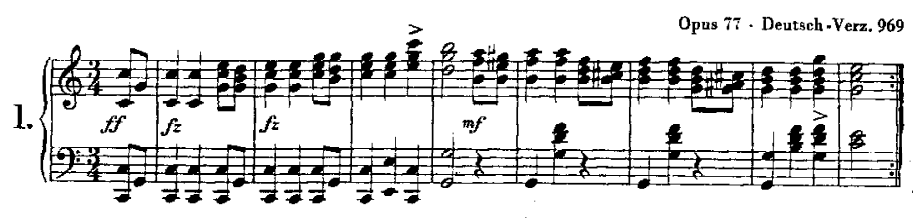

Contrastingly, waltz No. 2 is soft in dynamic level but also reveals a right-hand melody in continuous octaves.

Example 2-2. "Zwölf Valses nobles," $\quad$ D. 969, No. 2, mm. 1-5

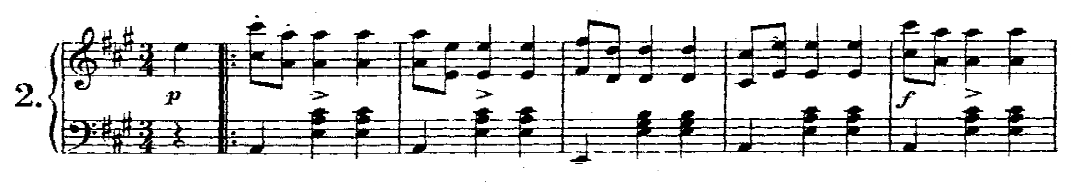

In waltz No. 3, we discover chords played in both hands, at a quiet dynamic level. Playing chords softly, but with good voicing, presents a challenge for the pianist. Example 2-3. "Zwölf Valses nobles" $\quad$ D. 969, No. 3, mm. 1-8

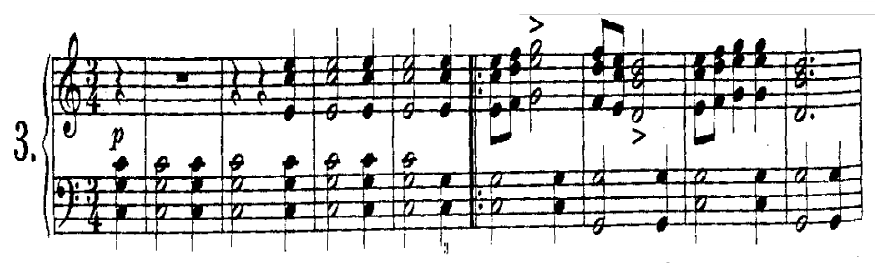

Schubert wrote some of his waltzes in minor keys, which is unusual in early nineteenth-century waltzes. Examples of minor-key waltzes appear in D. 128, No. 6 (c minor), and D. 790, No. 5 (b minor). Also, some waltzes begin in minor keys but finish in major. 
For example, in Zwölf Grazer Walzer, D. 924, No. 9 begins in A minor but ends in C major. In Zwölf Walzer, D. 145, No. 6, the B minor waltz, finishes in B major. Example 2-4. "Zwölf Walzer" D. 145, No. 6, mm. 1-6 and mm. 30-32

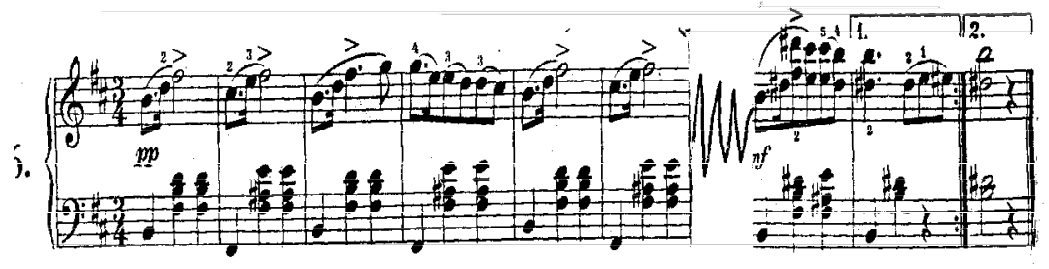

In the fourteenth waltz of Sechsunddreissig Originaltänze, D. 365, an unexpected modulation appears. This waltz starts in the key of D-flat major but it modulates to A major, rather than to A-flat, at the end of the first half. ${ }^{17}$

Example 2-5. "Sechsunddreissig Originaltänze" $\quad$ D. 365, No. 14, mm. 9-16

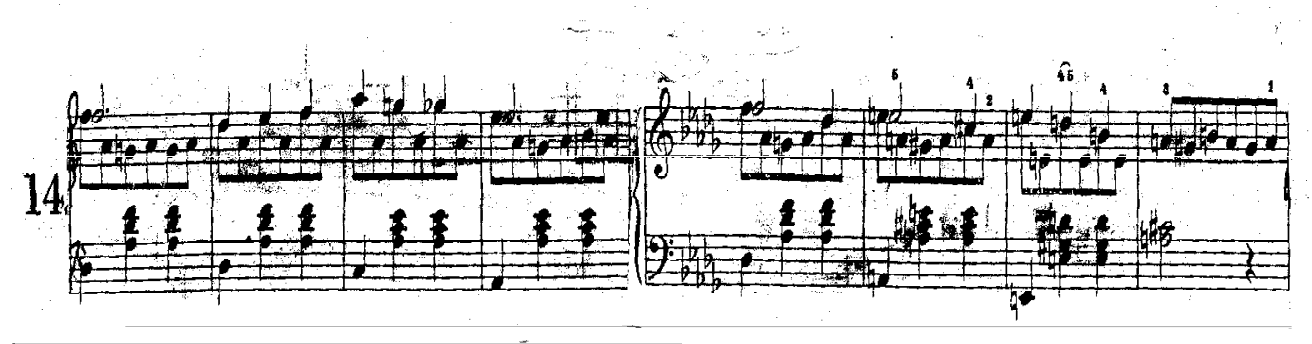

Most of Schubert's waltzes are in binary form, but a few of the waltzes, such as D. 924, No. 10, are in ternary form. In addition, Schubert inserted an eleven-bar Introduzione in his Zwölf Wiener Deutsche, D. 128, and the waltzes in D. 139 and D. 146 have trio sections.

In Schubert's waltzes, three different types of accompaniment appear:

1. The typical "oom-pah-pah" (bass-plus-chords) style (as shown in Examples 2-4 and 2-5 above);

2. A broken-chord style, which is demonstrated in D. 790, No. 5 (Example 2-6); and 3. An octave style, which is demonstrated in D. 783, No. 16 (Example 2-7) 
Example 2-6. "Zwölf Deutsche Tänze," D. 790, No. 5, mm. 1-8

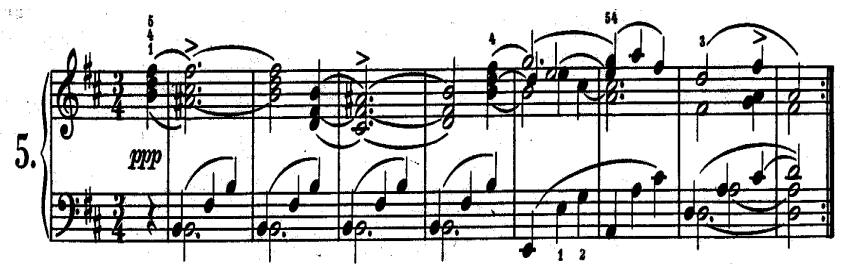

Example 2-7. "Sechzehn Deutsche Tänze" D. 783, No.16, mm. 1-8

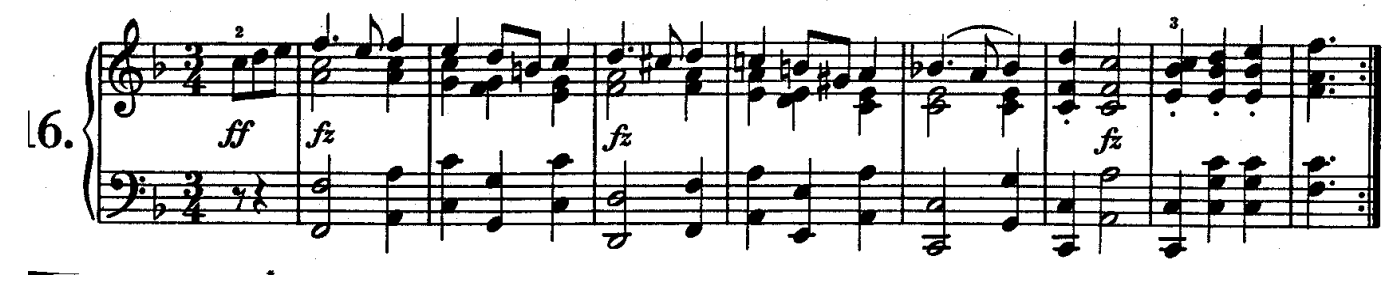

Schubert's waltzes are useful as pedagogical repertoire for intermediate to lateintermediate students because of their simple rhythmic patterns in regular three-four meter. ${ }^{18}$ In addition, most of them are written on a small scale, both in length and also in their technical demands.

In general, Schubert's waltzes reveal short forms, lyrical melodies, unexpected modulations, and the occasional use of minor keys. We see music intended for dancing, rather than a major evolution of waltz form, despite the charm and beauty of the material. 


\title{
Carl Maria Von Weber (1786-1826)
}

Weber's famous "Invitation to the Dance," Op.65, was composed in 1819 and published in 1821. The key of the "Invitation to the Dance" is D-flat major. Weber's "Invitation to the Dance" is the first, and still perhaps the most brilliant and poetic, example of the Romantic concert waltz. This waltz is dedicated to Weber's wife, Caroline, and it has a programmatic framework which portrays a miniature drama:

\begin{abstract}
First approach of the dancer [bars 1-5] to whom the lady gives an evasive answer [5-9]. His more pressing invitation[9-13: note the insistence of the added grace-notes]; her acceptance of his of his request [13-16]. Now they converse in greater detail; he begins [17-19]; she answers [19-21]; he with heightened expression [21-23]; she responds more warmly [23-25]; now for dance! His remarks concerning it [25-27]; her answer [27-29]; their coming together [29-31]; their going forward; expectation of the beginning of the dance [31-35]. The Dance. End: his thanks, her reply and their parting. Silence. ${ }^{19}$
\end{abstract}

Of all early waltzes, the "Invitation to the Dance" probably exerted the most significant influence on the development of future waltzes, because Weber not only changed the venue of the waltz from the dance hall to the concert stage but also greatly expanded the formal structure of the waltz. ${ }^{20}$

The formal structure of Weber's famous waltz shows an introduction followed by a series of waltzes, with a coda that refers back to thematic material heard before. tempo also changes se

The tempo also changes several times. The beginning and the coda have the same tempo (moderato), and their themes are the same. According to The New Harvard Dictionary, the waltz in the late eighteenth-century used a fast tempo. ${ }^{21}$ Weber's dances are also fast, Allegro Vivace or Vivace. 
Example 2-8. "Invitation to the Dance" mm. 36-43

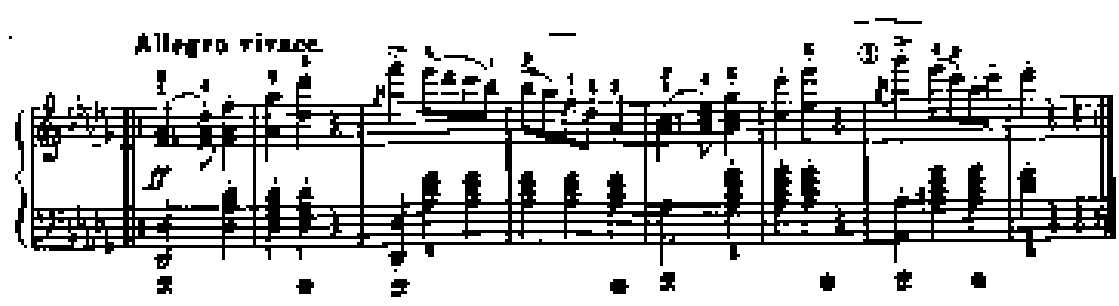

The thematic ideas in Weber's "Invitation to the Dance" reflect the stories of the various waltzes. For example, in the second waltz, the ascending and descending scale passages seem to be describing the whirling motions of the partners.

Example 2-9. "Invitation to the Dance" mm. 60-71

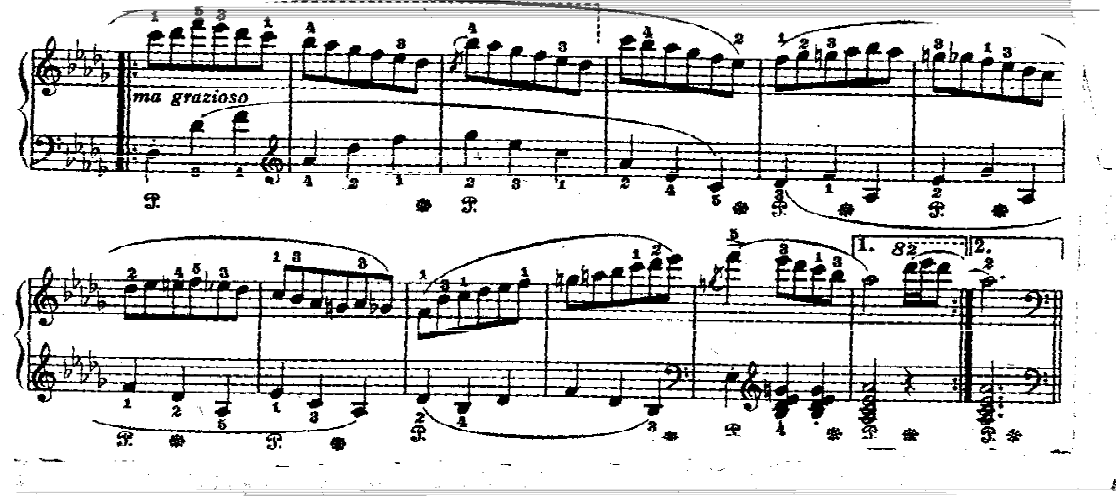

In mm. 96-127, a melody using quarter notes appears on the downbeat of each bar. Also, this waltz is marked "wiegend," which means "rocking"; thus, this waltz describes the feeling of gently swaying back and forth. 
Example 2-10. "Invitation to the Dance," mm. 96-100

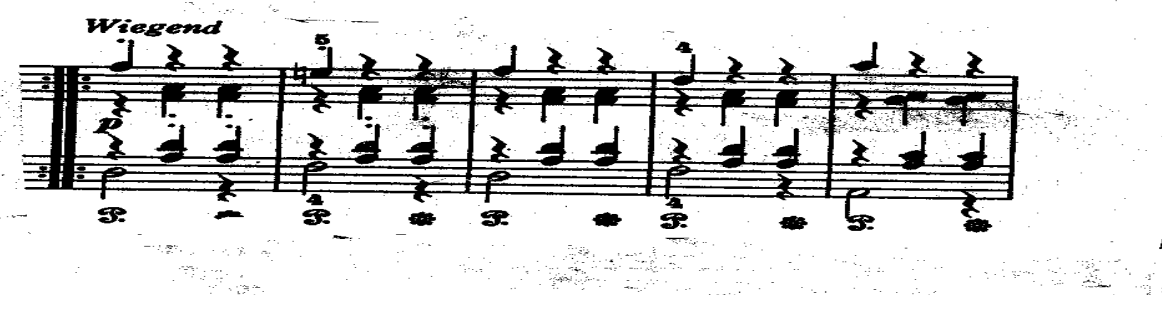

The key changes from D-flat major to C major (Example 2-11) and Weber borrows the melody from the beginning section of the waltz.

Example 2-11. "Invitation to the Dance" mm. 249-256 and mm. 257-260

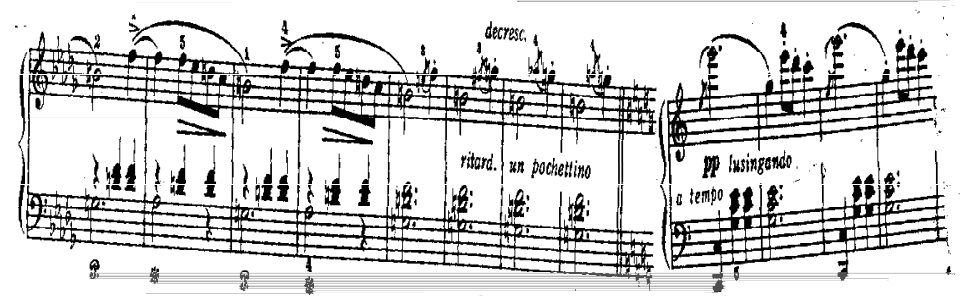

Compared to Schubert's short and moderately easy waltzes in binary or simple ternary form, Weber's "Invitation to the Dance" employs a much longer form including an introduction, series of waltzes, and a coda. In addition, Weber's waltz requires virtuoso technique by the performer.

In 1841, Berlioz orchestrated Weber's "Invitation to the Dance" for his Paris performance of Der Freischütz. ${ }^{22}$

\section{Frédéric Chopin (1810-1840)}

Chopin wrote at least seventeen waltzes, and we know of one or two others that have been lost. ${ }^{23}$ Chopin is credited with transporting the waltz from the Viennese dance hall to the salons of the Parisian aristocracy. ${ }^{24}$ Chopin's waltzes are characteristically elegant, joyful, carefree, and brilliant, but some of his waltzes convey melancholy and 
sadness. In their virtuosity, most of Chopin's waltzes resemble Weber's "Invitation to the Dance," an elegant, bravura piece.

Chopin uses the ABA formal structure for his waltzes; a contrasting middle section comes between the first and final sections. Some waltzes also include introductions and codas.

The majority of Chopin's waltzes are in major keys, but five waltzes of the seventeen are in minor keys. These five are

Grande valse brillante in A Minor, Op. 34, No. 2: Lento (1831)

Valse in C-sharp Minor, Op. 64, No. 2: Tempo giusto (1829)

Valse in B Minor, Op. 69, No. 2: Moderato (1829)

Valse in F minor, Op. 70, No. 2: Tempo giusto (1841)

Valse in E Minor, Op. Posthumous: Vivace (1830)

Three of Chopin's minor-key waltzes are nocturne-like in character, with a lyrical principal section: Op. 34, No. 2; Op. 64, No. 2; and Op. 69, No. 2.

Among the major-key waltzes of Chopin are five in A-flat:

Grande valse brillante, Op. 34, No. 1: Vivace (1835)

Grande valse, Op. 42: Vivace (1840)

Valse, Op. 64, No. 3: Moderato (1846-7)

Valse, Op. 69, No. 1: Lento (1835)

Valse, Op. Posthumous (1827)

There are two E-flat major waltzes:

Grande valse brillante, Op. 18: Vivo (1831)

Valse, Op. Posthumous (1829-1830)

Two D-flat major waltzes:

Valse, Op. 64. No. 1: Molto Vivace (1846-7)

Valse, Op. 70. No. 3: Moderato (1829)

One E major waltz: Valse, Op. posthumous: Tempo di Valse (1829)

One F major waltz: Grande valse brilliante, Op. 34, No. 34: Vivace (1838)

One G-flat Major waltz: Valse,Op. 70, No. 1: Molto Vivace (1833) 
Two of the waltzes are known by nicknames: "Minute Waltz" (Op. 64, No. 1) and "L’adieu" (Op. 69, No. 2). ${ }^{25}$

Chopin's waltz introductions display various characters, compared to those of Schubert and Weber. Chopin's Waltz in A-flat major, Op. 42, begins with a long trill introduction (eight bars: twenty-four beats).

Example 2-12. "Grande valse" Op. 42, mm. 1-8

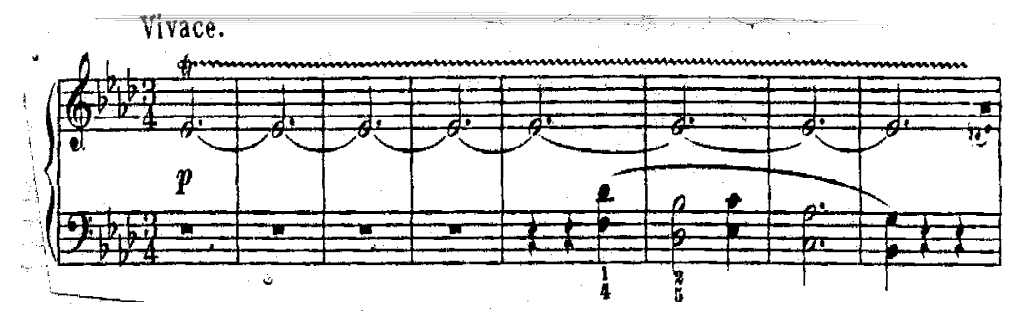

Other martial, ceremonial or fanfare-like introductions may be heard in the Op. 18 and Op. 34 waltzes, and their codas are brilliant as well. ${ }^{26}$

In Op. 42, "Grande valse," a two-against-three rhythm appears in the main theme.

Example 2-13. "Grande valse," Op. 42, mm. 9-12

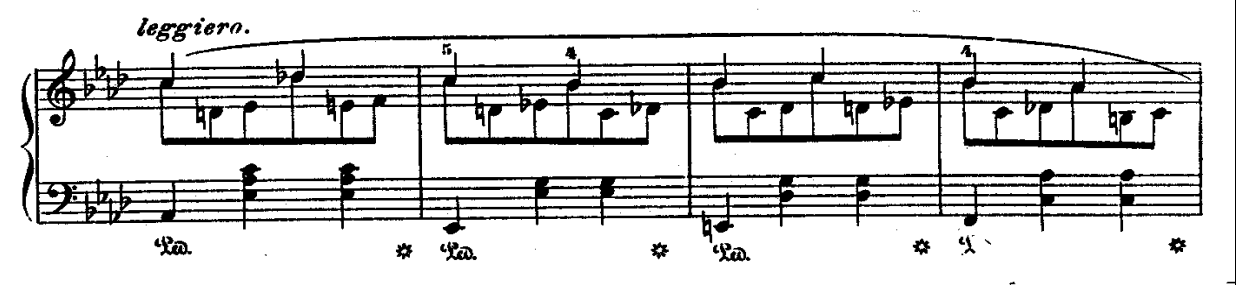

Chopin's Waltz in E minor, Op. posthumous (1830), provides a characteristic example for further discussion. This waltz is in ABA form with a tempo marking of Vivace and its formal structure is:

Introduction- A 12 1- B 1212 1-A' 1 -Coda

The introduction starts with an eight-measure E-minor broken chord and an 
accompaniment in long pedal notes.

Example 2-14. "Waltz in E minor" mm. 1-6

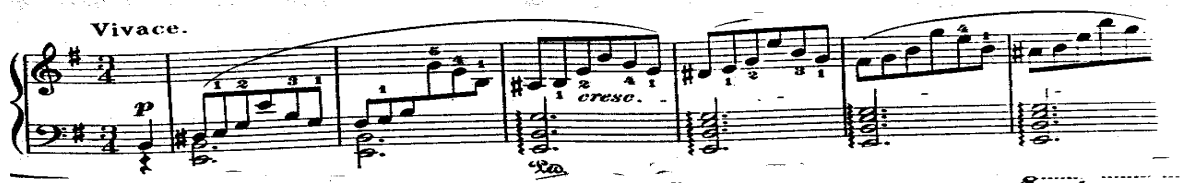

The A section reveals two themes. Chopin decorates the first theme with ornamental notes, mordents and grace notes.

Example 2-15. "Waltz in E minor" mm. 9-13, first theme of A section

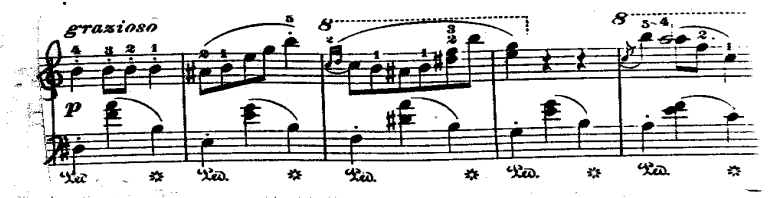

Similar melodic ornamentation appears in several of Chopin's other waltzes, such as Op. 34, No. 1; Op. 69, No. 1; and Op, 70, No.1 and No. 2.

The second theme is short and marked "dolce legato." Its smooth character contrasts with the first theme. In addition, both right and left hands descend chromatically.

Example 2-16. "Waltz in E minor" mm. 25-28, second theme of A section

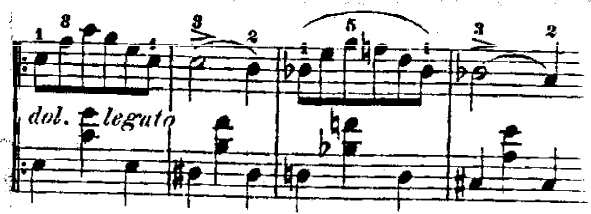

After the second theme the first theme is repeated.

The B section also has two main themes and is in the parallel key, E major. As in the first theme in the A section, the melody of the first theme in the B section is ornamented. 
Example 2-17. "Waltz in E minor," mm. 57-64, first theme of B section

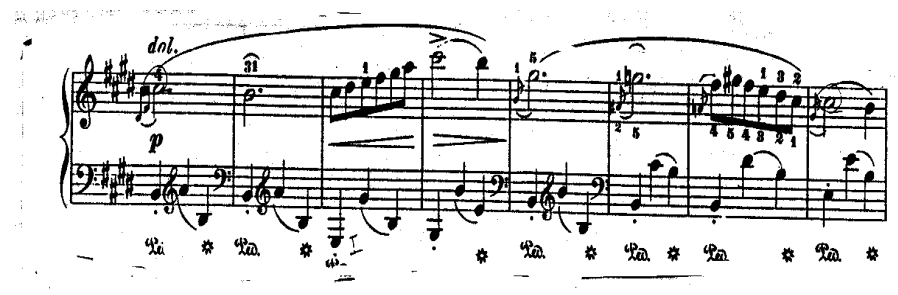

The second theme in the B section starts with a dynamic level of fortissimo. This section of the piece reflects a very different mood from the previous section and it is the loudest part of the entire piece. Harmonically, this section starts with a definite key change from E major to G-sharp major.

Example 2-18. "Waltz in E minor," mm. 89-95, second theme of B section

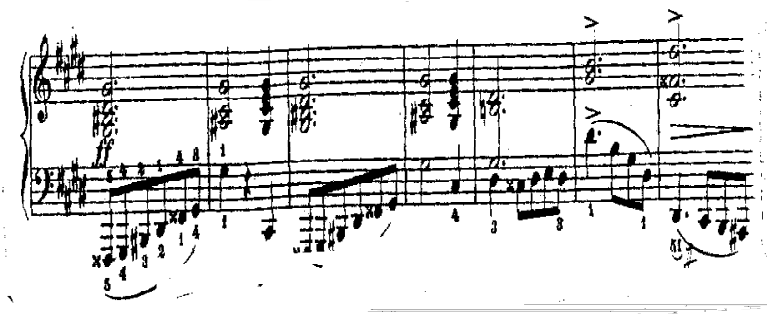

After the B section, the A section reappears, this time without the second theme. From the first theme, it connects directly to an intense coda section. A similar coda occurs in the Op. 42 waltz, as shown in examples 18 and 19. 
Example 2-19. $\quad$ "Waltz in E minor," coda, mm. 149-152

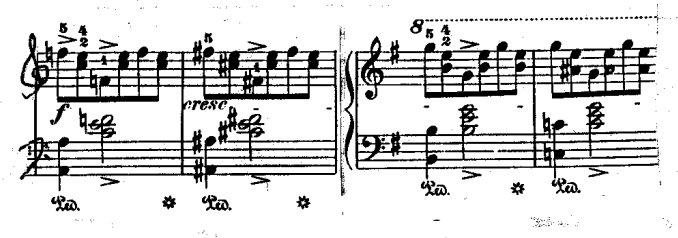

Example 2-20. "Grande valse" Op. 42, beginning of coda

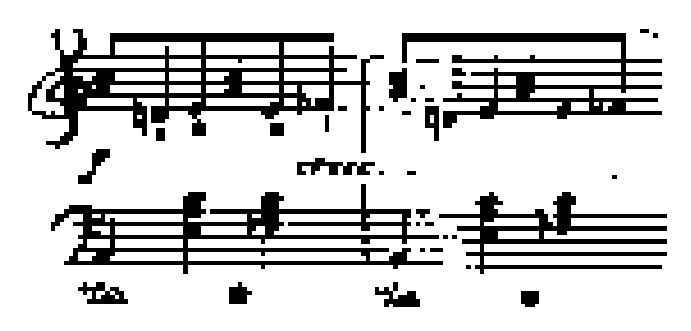

The waltz concludes by alternating twice between the dominant (B major) and tonic (E minor). Generally, this waltz is elegant and brilliant, but these are some possible weaknesses in the formal structure in the B section. Because the main theme repeats many times with just small changes in range, it poses a musical challenge to the performer, who needs to sustain interest in the many repetitions. For this waltz, the Mikuli edition $^{27}$ suggests a composition date of 1830(?) when Chopin was twenty. For that reason, it might be considered an immature work, but it has a dynamic introduction and coda, and the first melody in the A section is very lovely.

Compared to waltzes by Schubert, Chopin's waltzes are much longer and more technically demanding. They also employ ABA structure rather than binary form, with various introductions and codas. 


\section{Johannes Brahms (1833-1897)}

Originally, the Sixteen Waltzes, Op. 39, by Brahms were composed in 1865 for piano duet (one piano, four hands) and published in 1866. The original piano duet version was dedicated to Dr. Eduard Hanslick, the famous Viennese music critic. ${ }^{28}$

Eventually, Brahms' Op. 39 came to have three additional versions: Solo piano (published in 1867), Simplified solo (published in 1867) and an arrangement of five waltzes for two pianos (published in 1867). Unless otherwise noted, examples used in this study refer to the solo-piano version.

These waltzes show diverse styles, ranging from organ-chorale sonorities in No. 5, the sentimental mood of No. 7, the sigh-figure rhythms in No. 9 and the good humor of No. 10. Also, some of these waltzes employ moderate technical difficulties, such as writing the melody in octaves (Waltzes 1, 13, 16), large skips (Waltz 6), continuous chord passages (Waltzes 2, 7, 8, 12, 14 and 15), and parallel thirds (Waltzes 5, 11, and 14).

These waltzes were influenced by Schubert's waltzes, in imitation of the gentle swaying style of the Ländler ${ }^{29}$ and a simple formal structure (AB or $\left.\mathrm{ABA}\right)$.

Waltz No. 1 opens with three eighth-note upbeats and it has a march-like character, beginning with staccato notes in both clefs. The legato playing in the B section contrasts with the articulation of the A section. The main motive of the B section comes from measures 7-8 of the A section. 
Example 2-21. "Walzer" No. 1, mm. 1-13

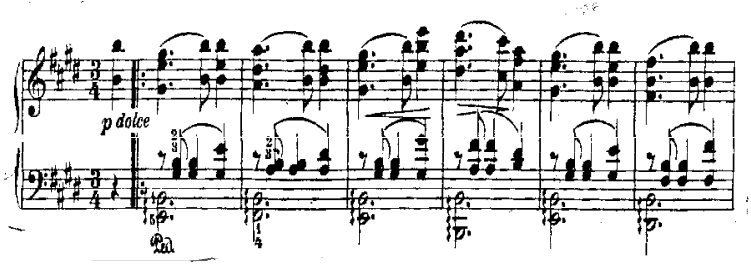

Waltz No. 2 is in E major and has a thick chordal texture. The accompaniment reveals syncopated rhythms, and dotted rhythmic figures in the melody occur throughout the piece.

Example 2-22. "Walzer" No. 2, mm. 1-6

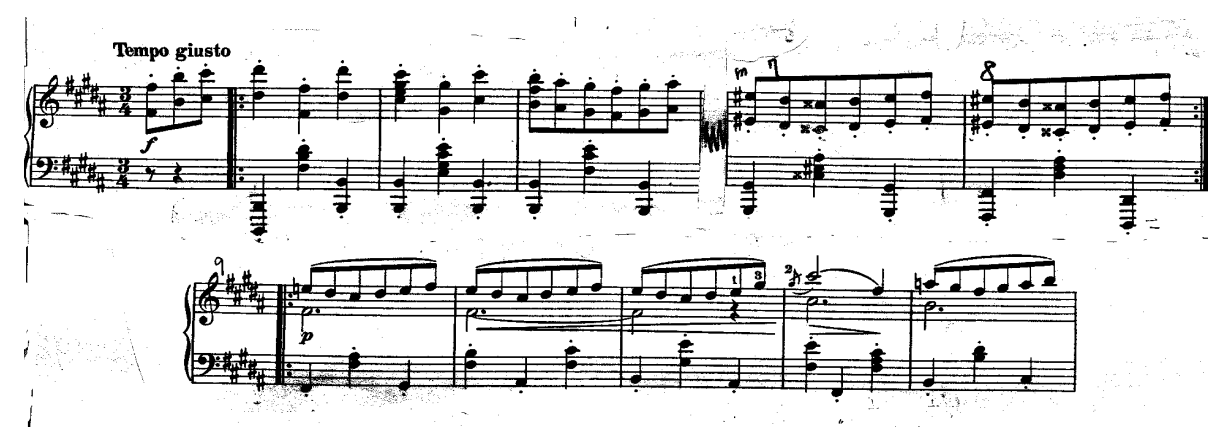

Waltz No. 3 is a short piece in g-sharp minor. The beginning employs a simple melody with a basic "oom-pah-pah" waltz accompaniment (see Example 2-23), but in measures 13-14 the melody appears in the inner voices with stems down in the treble clef (see Example 2-24).

Example 2-23. "Walzer" No. 3, mm. 1-3

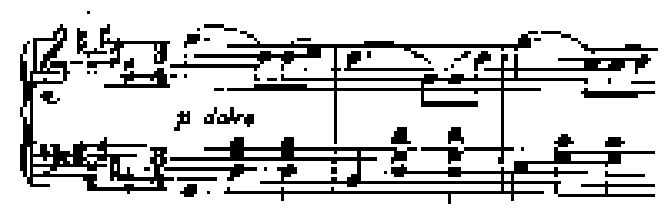


Example 2-24. "Walzer" No. 3, mm. 13-16

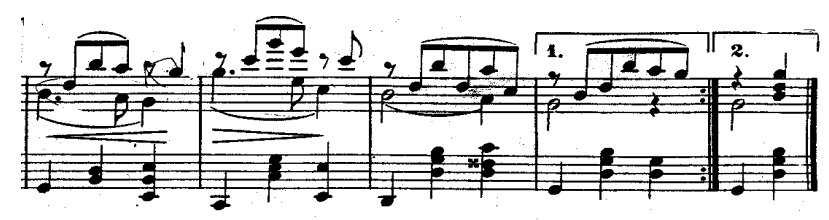

As in Waltz No. 3, the melody of No. 5 usually appears in the inner voices, but sometimes it can also be found in the upper voice. In mm. 1-4, there are octaves between the soprano and tenor voices. This is similar to the duet version, in which the right hand of the primo part is in octaves.

Example 2-25. "Walzer" No. 5, mm. 1-8

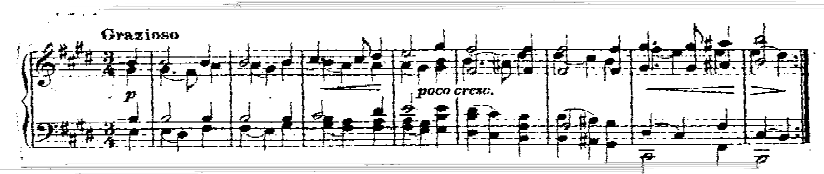

Example 2-26. " Walzer" No. 5, mm. 1-4

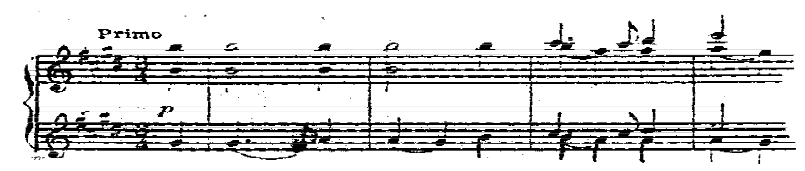

Waltz No. 6 is light in character with staccato notes in the first and last repeated sections. Also, the joyful mood of waltz No. 6 contrasts with the thick texture and organlike character of Waltz No. $5 .^{30}$

In No. 6, Brahms employs cross rhythms and a writing style that includes big skips between the notes in both hands at once. 
Example 2-27. "Walzer" No. 6, mm. 1-4

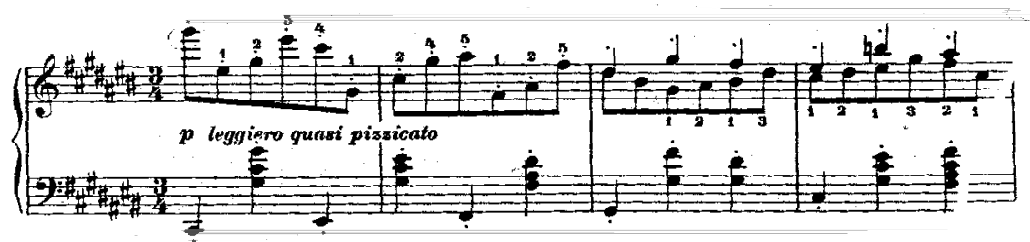

However, the B section contrasts with the A section because the melody notes are close to each other, while the accompaniment continues its leaps.

Example 2-28. "Walzer" No. 6, mm. 9-14

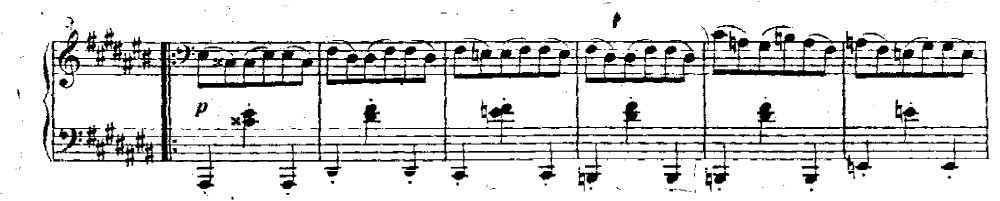

In $\mathrm{m} .11$ of the A' section, Brahms adds an E-sharp grace note which is emphasized not only because of its dynamic level $(f p)$ but also because the piece returns to $\mathrm{C}$-sharp major from the A major of the B section.

Example 2-29. "Walzer" No. 6, mm. 21-23

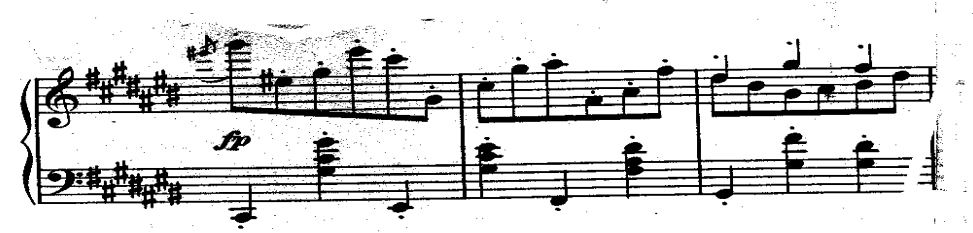

Waltz No. 7 changes tempo to Poco Piú Andante from the Vivace of number 6. It has a thick texture and seems to have an accent on the second beat of measures 2 and 4 because of the half notes on second beats. 
Example 2-30. "Walzer" No. 7, mm. 1-8

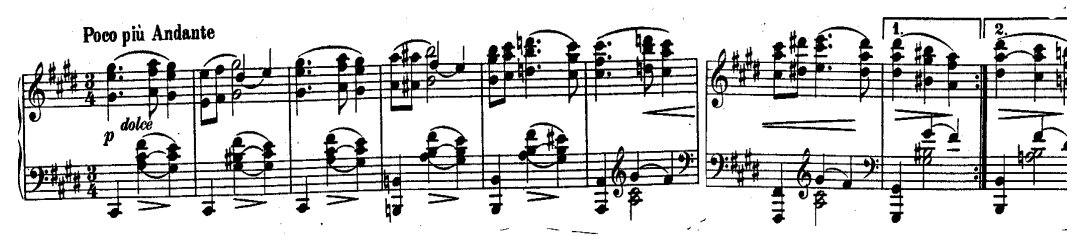

Near the end of waltz No. 7, the rhythmic accent shifts back to the first beat, as shown in Example 2-31 below.

Example 2-31. "Walzer" No. 7, mm. 26-28

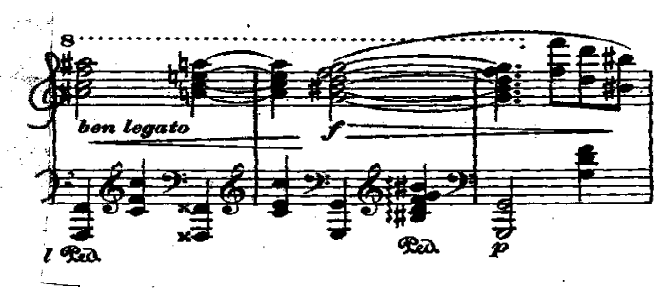

In waltz No. 8, the rhythmic features are like waltz No. 2 and the dotted rhythms are consistent throughout the piece. The texture of waltz No. 8 shows thick chordal writing.

Example 2-32. "Walzer" No. 8, mm. 1-7

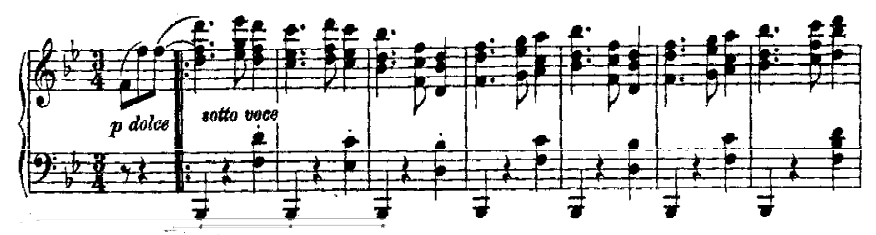

As in waltz No. 8, the rhythmic pattern of waltz No. 9 never changes. The sighing rhythmic effect of No. 9, in d minor, is similar to No. 18 of Schumann's

"Davidbündler Tänze," Op. 6. 
Example 2-33. Brahms "Walzer" No. 9, mm. 1-6

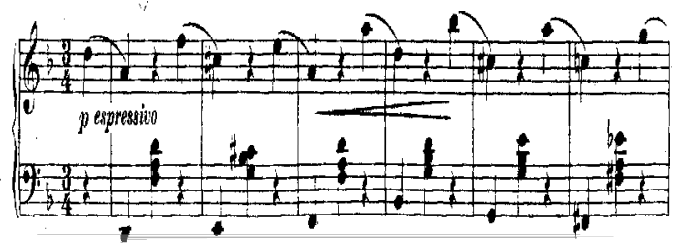

Example 2-34. Schumann "Davidbündler Tänze" No. 18, mm. 1-10

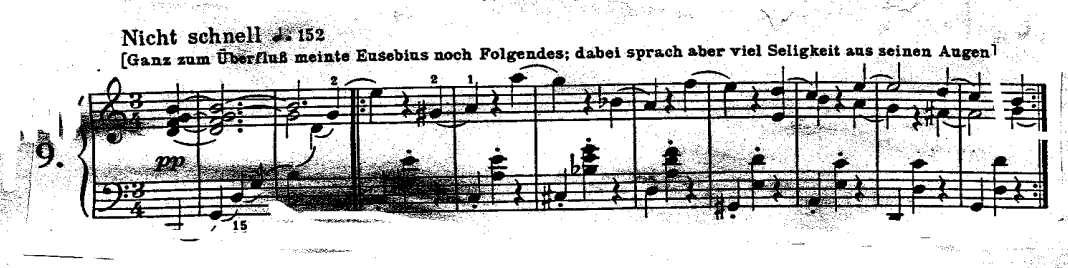

Waltz No. 9 includes some unusual modulations: d (m. 1)- E-flat (m. 9)-d (m. 13)$\mathrm{F}$ (m. 17), finishing on the dominant of $\mathrm{D}$ major.

Example 2-35. "Walzer" No. 9, mm. 20-24

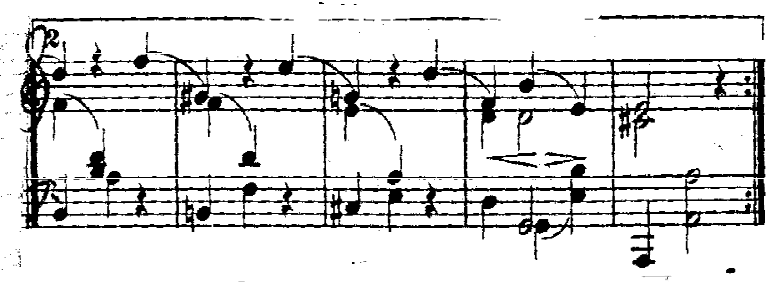

Waltz No. 10 begins with the D chord, dominant of $\mathrm{G}$ major. This is a short sixteen-bar waltz, marked poco scherzando.

Waltz No. 11 is in B minor and ends in the parallel-major key of B major. Unlike the other waltzes, No. 11 uses grace notes as the melody every two measures. Both Nos. 10 and 11 employ "double thirds" in the right hand (shown in Examples 2-36 and 2-37 below). 
Example 2-36. "Walzer" No. 10, mm. 1-5

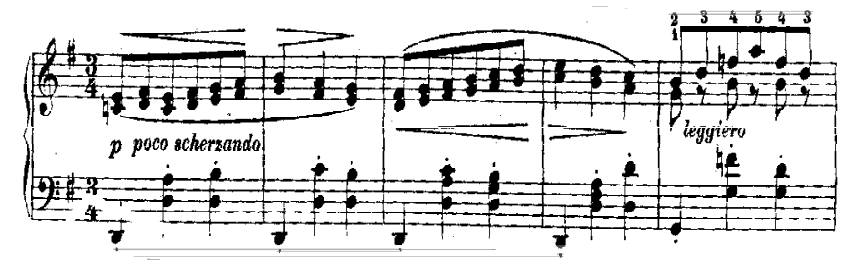

Example 2-37. "Walzer" No. 11, mm. 1-8

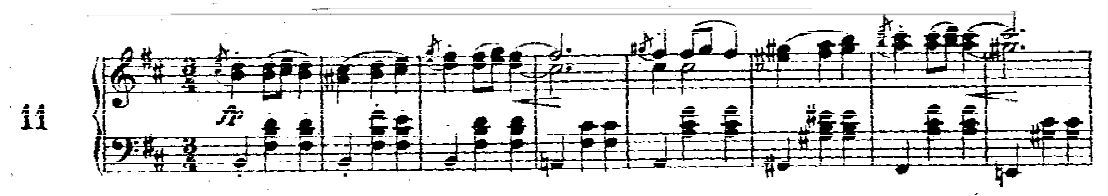

In waltz No.12, the same rhythmic figuration continues throughout the piece. The accompaniment is unique within the set because it is in broken chord style with low bass pedal points. The key relationship between waltzes No. 11 in B and No. 12 in E is dominant-tonic. The second section of the waltz starts in $\mathrm{E}$ minor but ends in $\mathrm{E}$ major. Also, in mm. 5-7, the melody appears in inner voices.

Example 2-38. "Walzer" No. 11, mm. 37-40

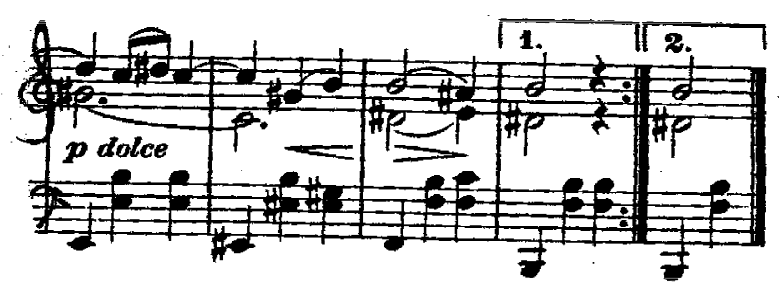

Example 2-39. "Walzer" No. 12, mm. 1-7

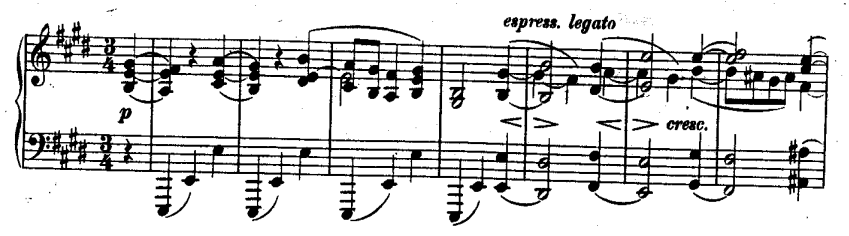


The key relationship between waltzes No. 13 and No. 14 is major to relative minor (No. 13 is in B major and No. 14 is in G-sharp minor).

Waltz No. 14 is the longest of the sixteenth waltzes. As in No. 11, grace notes ornament the melody. The rhythm of this waltz implies that the second beat is accented. In the middle part, the right hand has a descending scale that is like a short cadenza. Example 2-40. "Walzer" No. 14 mm. 1-3 and mm. 23-24
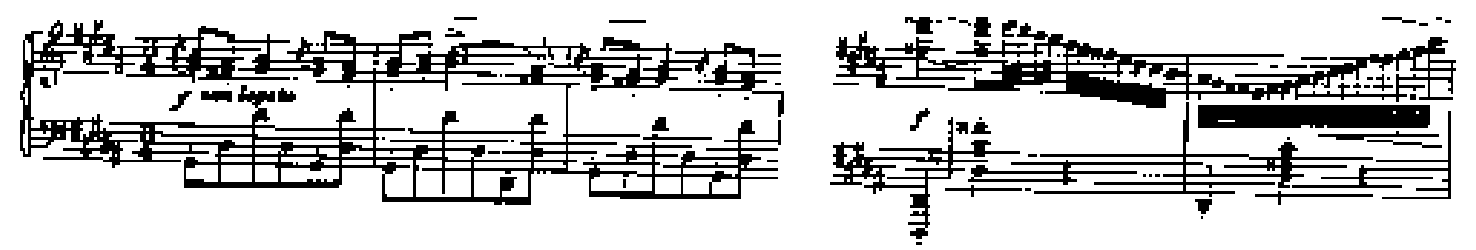

Waltz No. 14 makes moderate technical demands of the performer.

Waltz No. 15, in A-flat major, is the best known of the sixteen Brahms waltzes. Its grace and gently swaying character have delighted audiences for years. The accompaniment uses arpeggios that make it smoothly flowing. In mm. 29-36, Brahms adds a short coda to the ABA architecture.

Example 2-41. "Walzer" No. 15, mm. 1-6

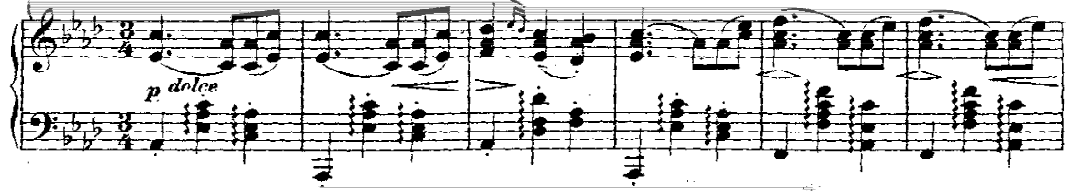

Example 2-42. "Walzer" No. 15, mm. 29-30, beginning of coda

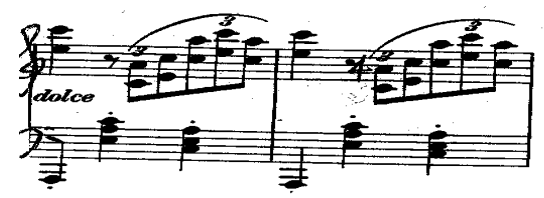


The last waltz, No. 16, is in C-sharp minor. This piece is especially interesting in its use of two simultaneous melodies, which pass gracefully from voice to voice throughout the waltz.

Example 2-43. "Walzer" No. 16, mm. 1-16

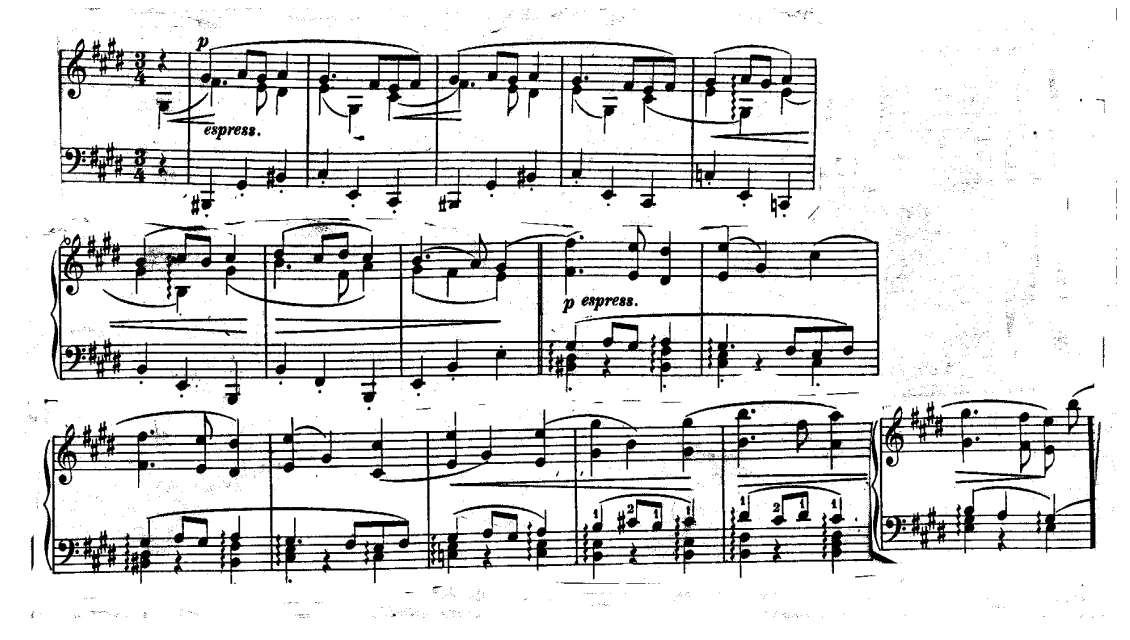

Even though Brahms does not greatly extend the form of the waltz as a genre, the individual pieces of Op. 39 show ingenious thematic materials, rhythms and key relationships. We also see typical elements of Brahms' writing style, such as thick textures, melodies in inner voices, syncopated rhythms, and rich sounds in low-tessitura accompaniments. This set is fun to play for amateurs or concert pianists alike, in any of its solo or four-hands versions.

Several years after completing Op. 39, Brahms continued his output of waltzes with two sets of Liebeslieder Waltzer for vocal quartet with accompaniment by two pianos, Op. 52a and Op. 65a. The first set was composed and published in 1874, and the second in 1877 . These pieces are based on the old tradition of German social song. ${ }^{31}$ 


\section{Franz Liszt (1811-1886)}

Liszt wrote four "Mephisto Waltzes." The first was composed in 1859-1860 and published in 1862, the second was composed and published in 1881, the third was composed in 1883, and the fourth remained unfinished at Liszt's death. The first and second "Mephisto Waltzes" were written first as orchestral pieces and later transcribed for solo piano. $^{32}$

Of these four waltzes, the first is by far the best known. In its piano version, it is an outstanding example of the nineteenth-century virtuoso showpiece. This first "Mephisto Waltz" is also dramatically effective as a programmatic, orchestral tone-poem.

It was written during Liszt's Weimar period, 1841-1861, and the first performance of the orchestral version took place in Weimar on March 8, 1861, at a "Hofkonzert im Schloss" ("court concert in the castle"), with Liszt conducting. ${ }^{33}$

The inspiration for the first Mephisto Waltz is the second of two episodes in the poem "Faust," by Lenau. The piece is subtitled, "Der Tanz in der Dorfschenke" ("The Dance at the Village Inn")

\footnotetext{
The scene is supposed to be a village inn which Faust and Mephisto enter, in search of love, on hearing the music from inside. The peasants are dancing, and the attention of Faust is riveted by the landlord's daughter, who comes in to carry drinks to the dancers. Mephisto seizes the violin and his playing intoxicates the audience, who completely abandon themselves to love making under the influence of the music. As the dancing reaches its climax, the singing of a lark is heard in the starlit woods, through the open doors. Mephisto goes on playing, while, two by two, the dancers disappear into the night. The village maiden throws herself into the arms of Faust, and on the wings of music they, too, vanish into the woods. ${ }^{34}$
}

The primary key of the first "Mephisto Waltz" is A major, but there are several changing key signatures: 
A major: mm. 1-241

A-flat major: mm. 242-249

A major: mm. 250-349

D-flat major: mm. 350-492

E major: mm. 493-544

A-flat major: mm. 545-476

D-flat major: mm. 577-644

Chromatic ascending scales: mm. 645-649

B-flat major: mm. 670-701

A major: mm. 702-930

In this work, Liszt used mainly three-eight meter rather than the traditional three-four. However, in the beginning, the measures easily fall into four-four time, because of the way the notes are grouped.

Example 2-44. Liszt "Mephisto Waltz" No. 1, mm. 1-9 (Three-four sounding like Four-four)

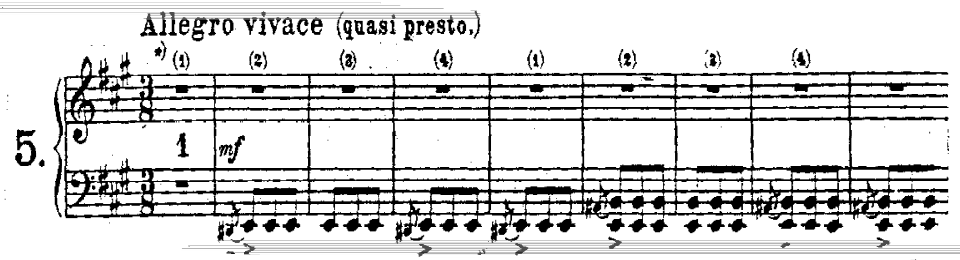

There are also tempo changes. This waltz is generally very fast in tempo, but Liszt includes a variety of tempo marks, such as Un poco meno mosso (ma poco) (mm. 350-461), Presto (mm. 466-492), Poco Allegretto e rubato (mm. 493-544), Presto (mm. 545-579) and Piú mosso (mm. 670-763). Meanwhile, the dynamics range from fff (mm. 301-305) to ppp (mm. 466-473).

\section{The general plan of the First "Mephisto Waltz"}

There are four sections in this waltz and their schemes are:

1. Introduction: Allegro Vivace (quasi presto). 
This section spans measures 1 through 110 . Note that the repeated E's start with grace notes, perhaps to suggest tuning the violin. The rhythm is also repeated in an ostinato pattern, while during $\mathrm{mm}$.

17-18 we see fragments of the first main theme.

2. First section: mm. 111-349

The first theme mm. 111-117, begins in A major.

3. Second Section: mm. 350-669

There are three main thematic motives:

Theme A: Un poco meno mosso, mm. 350-358

Theme B: mm. 382-389

Theme C: Presto, mm. 466-469

4. Final Section: Piú mosso, mm. 670-930

This section starts with the first theme, now in the key of B-flat, mm. 670-678. ${ }^{35}$

\section{Lisztian Pianistic Writing Styles}

The brilliant pianistic writing in the first "Mephisto Waltz" is similar to the effect of an orchestra. There are six distinctive pianistic writing techniques employed by Liszt in this work:

I. Dense, thick, repeated chords

Example 2-45. Liszt "Mephisto Waltz" No. 1, mm. 901-907

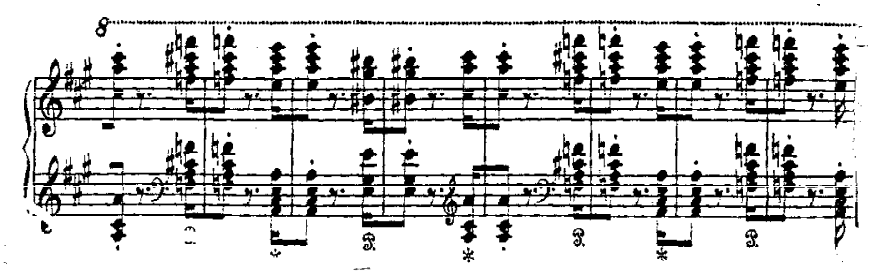


II. Chromatic passages both in scales and octaves

Example 2-46. Liszt "Mephisto Waltz" No. 1, mm. 165-169

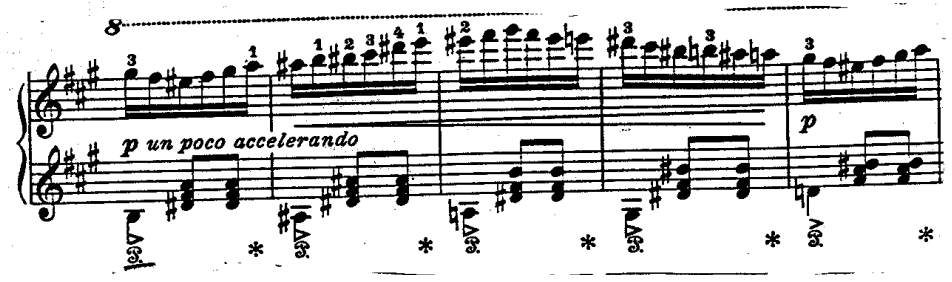

III. Octaves in all ranges

Example 2-47. Liszt "Mephisto Waltz" No. 1, mm. 185-192

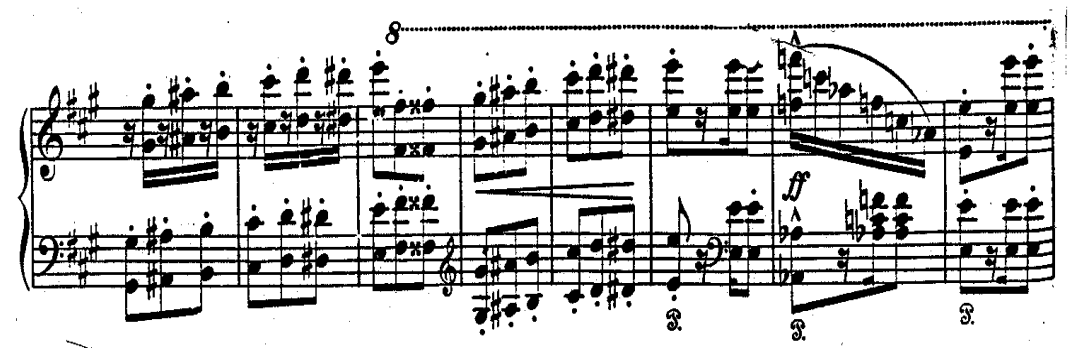

IV. Consecutive repeated notes

Example 2-48. Liszt "Mephisto Waltz" No. 1, mm. 633-638

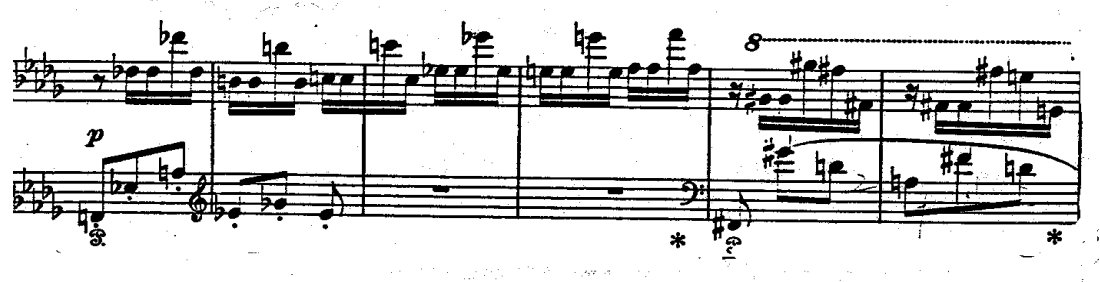


V. Sweeping arpeggios

Example 2-49. Liszt "Mephisto Waltz" No. 1, mm. 820-821

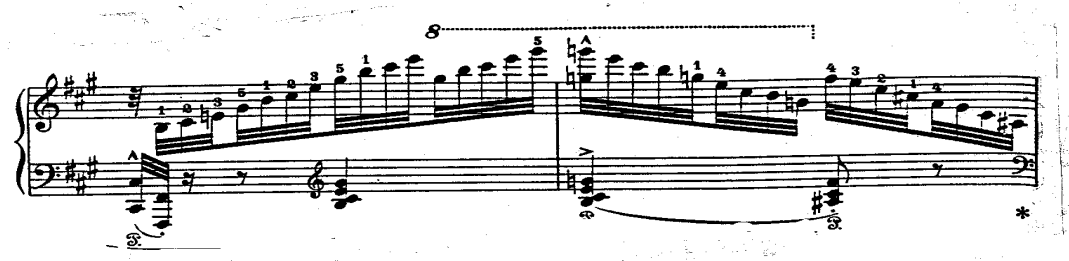

VI. Cadenza ${ }^{36}$

Example 2-50. Liszt "Mephisto Waltz" No. 1, m. 832

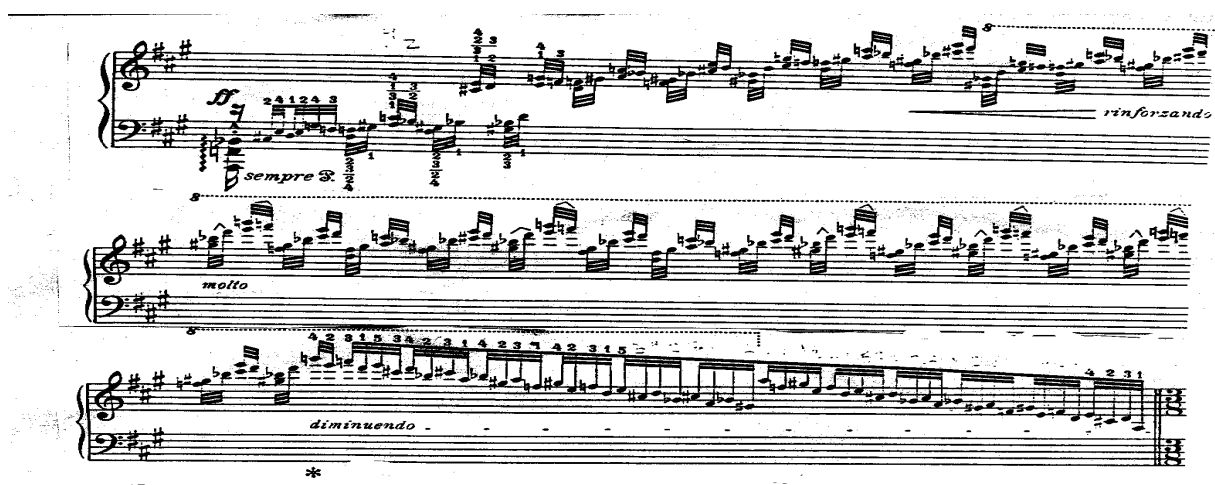

The distinctive rhythmic style of the first "Mephisto Waltz" is that of an ostinato. In the introduction, there are many repeated rhythmic patterns and the effect is similar to that created by beating of drum.

Example 2-51. Liszt "Mephisto Waltz" No. 1, m. 832

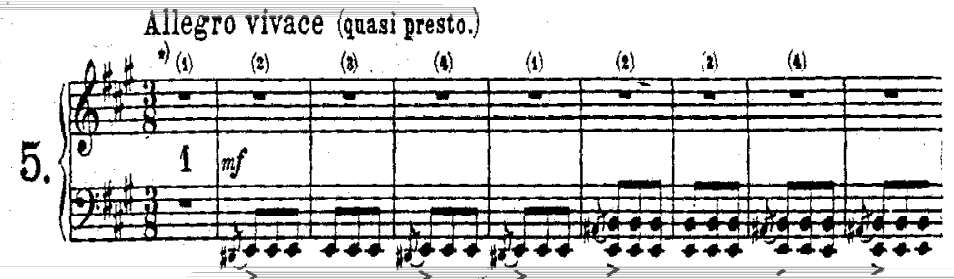


In Liszt's "Mephisto Waltz No. 1," there are two main contrasting themes, which reappear in thematic variations throughout the work. The first is marcato, the second is lyrical.

Example 2-52. Liszt "Mephisto Waltz" No. 1, mm. 111-116, marcato first theme.

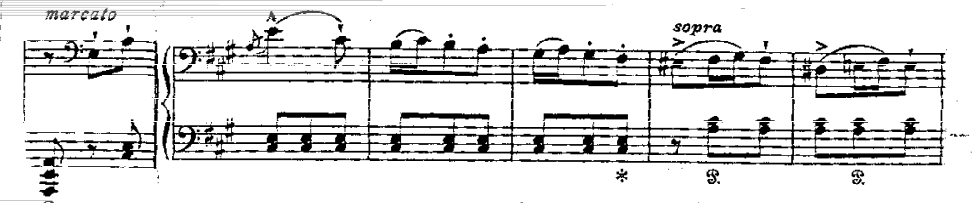

Example 2-53. Liszt "Mephisto Waltz" No. 1, mm. 350-354, lyrical second theme.

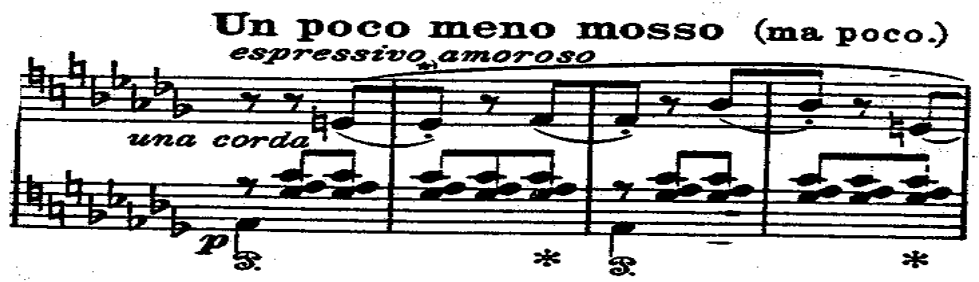

In the "una corda sempre" section (mm. 865-882), Liszt employs greater rhythmic variety, using shorter and longer values such as triplet, sextuplet, trills with fermatas and arpeggiated quarter notes. Also, this section describes the singing of a lark.

Example 2-54. Liszt "Mephisto Waltz" No. 1, mm. 865-882, "una corda sempre,"
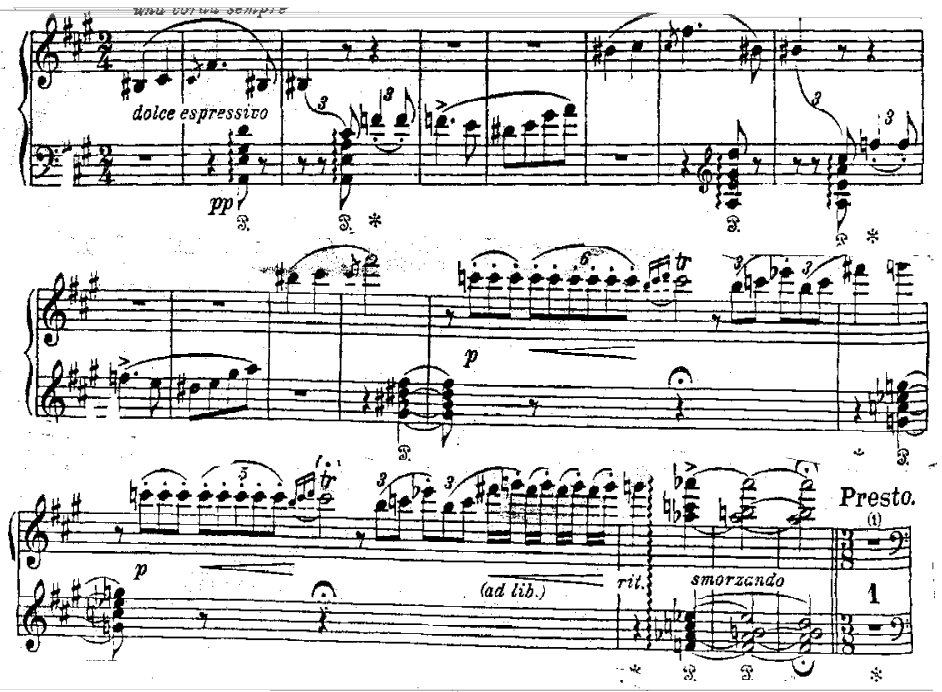
In "Mephisto Waltz" No. 1, Liszt sets the demonic story of Lenau's "Faust" effectively in part by demanding an enormous pianistic technique, with much of the difficulty caused by the fast tempo. Unlike other nineteenth-century composers' waltzes, the form of the first "Mephisto Waltz" is not based on ABA structure; furthermore, the tempo and meters also change frequently, as do the tonalities. Also, rather than the gentle swaying of the elegant traditional waltzes by Chopin and Brahms, Liszt described "Mephisto" Waltz No. 1 as a caricature of the dance itself. ${ }^{37}$ It is also much longer than any of the Brahms or Chopin Waltzes. The first "Mephisto Waltz" conveys dramatic "orchestral" effects in new ways.

Also, Liszt wrote several other waltzes, including "Valse de bravoura," "Valse mélancolique," "Caprice-Valse" and four sets of "Valses oubliées." These pieces are much less often played than the famous "Mephisto Waltz" No. $1 .^{38}$

\section{Robert Schumann (1810 - 1886)}

One of Schumann's best-known and most comprehensive works is Carnaval, Op. 9, composed in 1834-1835. This work is cyclic and also resembles a suite.

In Carnaval, Schumann created music using the four letters ASCH, the name of the home town of Ernestine von Fricken, with whom Schumann had had a love affair. ${ }^{39}$ There are two waltzes found in Carnaval, "Valse noble" (IV) and "Valse Allemande" (XVI).

In the "Valse noble" (IV), the four-note motive A, E-flat, C, B (in German music notation A-Es-C-H) appears in a slightly altered version at the beginning. ${ }^{40}$

Example 2-55. "Valse noble" mm. 1-4

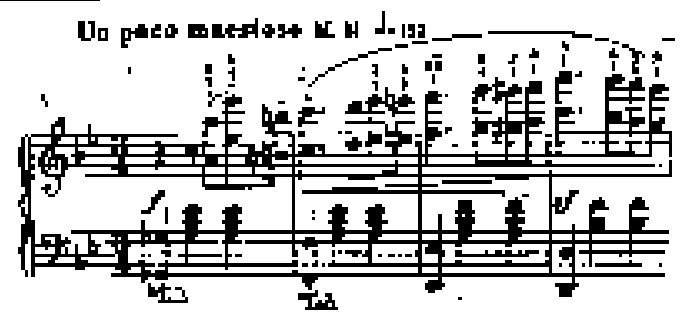

The "Valse noble" is in B-flat Major, and its tender and sensitive middle section contrasts with the forte legato octaves of the first section.

Example 2-56. "Valse nobles" mm. 9-13

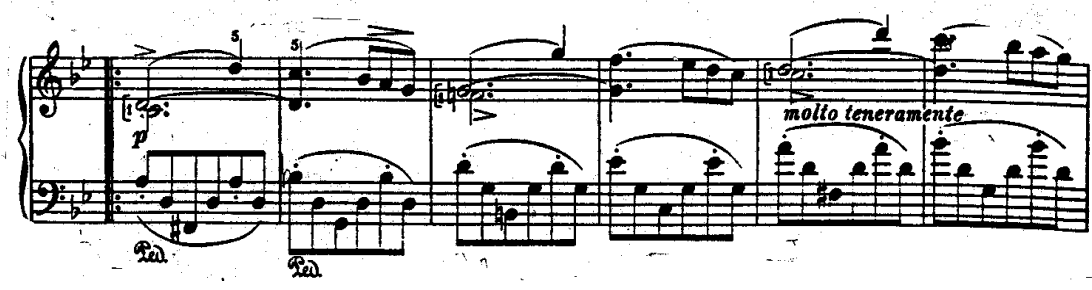


The accompaniment in the middle section reveals subdued, broken-chord styles. Schumann may have taken the title "Valse noble" from one of Schubert's dance sets.

The other waltz, "Valse Allemande," is only 24 measures long and the initial motto notes used in the beginning are A-flat, C, and B.

Example 2-57. "Valse Allemande" mm. 1-8

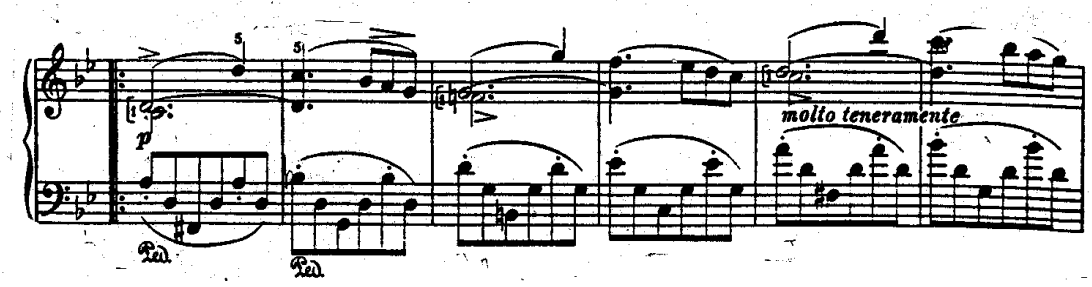

The sudden dynamic changes in the middle section range from forte to piano and at the ending range from pianissimo to fortissimo.

Example 2-58. "Valse Allemande" mm. 16-24

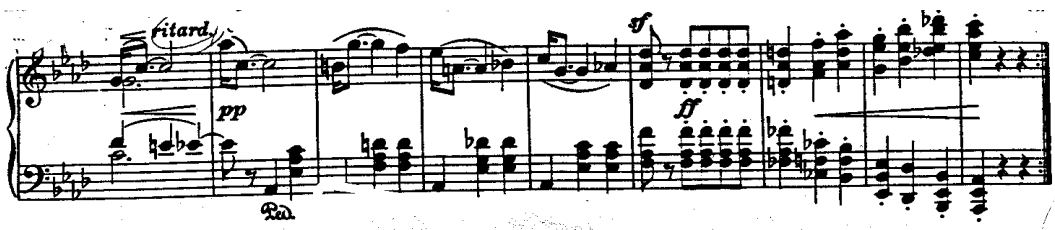

Some of the characteristics of the waltz can be found in some of Schumann's other works, such as the theme of Papillons and the theme of the Abegg Variations. The first theme of Papillons had extra significance to Schumann because it plays a prominent role as Florestan's motive in both Carnaval, Op. 9, and Die Davidsbündlertänze, Op. 6.

Now we can turn our attention briefly to other composers' waltzes during the nineteenth century in Germany, France, Bohemia, Russia, and Norway. 


\section{Germany}

Max Reger (1873-1916)

Waltzes in the spirit of Brahms. For piano solo, two sets of waltzes (both in

Op. 11, composed in 1893).

Other waltzes for piano duet (Waltz-Caprices, Op. 9, twelve pieces composed in in 1892)

Deutsche Tänze, Op. 10, (ten pieces, composed in 1893). ${ }^{41}$

\section{France}

Charles Gounod (1818-1893)

Waltzes appear in his small character pieces, which also included musettes, marches, pastorales and the like.

Vincent D'Indy (1851-1931)

Helvetia, Op. 17 (1882), a waltz in the style of Liszt. ${ }^{42}$

Camille Saint-Saëns (1835-1921)

"Minuet et Valse," Op. 56 (1878)

"Valse canariote," Op. 88 (1890)

"Valse mignonne," Op. 194 (1896)

"Valse nonchalante," Op. 110 (1898)

"Valse langoureuse," Op. 120 (1903)

"Valse gaie," Op. 139 (1913) ${ }^{43}$ 


\section{Other Countries of Western Europe Bohemia}

Antonin Dvorák (1841-1904)

A set of eight piano waltzes in his Op. 54 of 1880. In waltz No. 5, we see Chopin's influence, and two-against-three rhythms appear. ${ }^{44}$

\section{Russia}

Mily Balakirev (1837-1910)

Examples of waltzes his among character pieces. ${ }^{45}$

Peter Ilyich Tchaikovsky (1840-1893)

Op. 1 is titled "Waltz-Caprice." 46

Anton Rubinstein (1829-1894)

"Valse Caprice in E-flat" is a virtuoso piece with big skips in the melody. ${ }^{47}$

\section{Scandinavia}

Scandinavian composers were strongly influenced by German style. The bestknown Scandinavian composer who produced waltzes was Edvard Grieg (1843-1907).

Grieg was born in Bergen, Norway, and he was educated in Germany. ${ }^{48}$ In Grieg's largest collection of miniatures, consisting of the ten sets of "Lyric Pieces" (Op. $12,38,43,47,54,57,62,65,68$ and 71 (composed 1867-1901), appear four waltzes. The first waltz (Op. 2, No. 2) is short (only two pages long) and simple, with the traditional "oom-pah-pah" accompaniment. The Coda section reveals an alternation of major and 
minor tonalities (A major to A minor).

Example 2-59. Grieg's "Walzer" Op. 12, No. 2 mm. 71-79

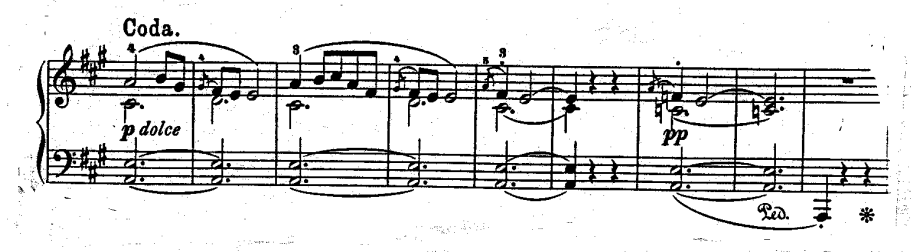

The second waltz is Op. 38, No. 7. This piece is also short (two pages long) like Op. 12, No. 2. There are three tempo markings in this piece. The beginning (A) is marked Poco Allegro (dotted half note $=60$ ) but the second section $(\mathrm{B})$ is marked Presto (dotted half note $=108$ ). The B section is almost twice as faster as the first A section. The two final chords of the piece are marked Lento; these last two chords are exactly the same as those at the end of the first A section.

Example 2-60. "Walzer" Op. 38, No. 7, mm. 1-2, mm. 17-18 and mm. 51-53

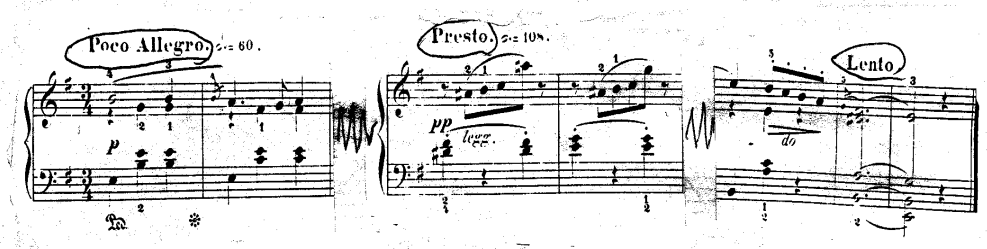

The third waltz appears as Op. 47, No. 1, and bears the title "Valse-Impromptu." This waltz is longer and seems much more mature and complex than the two previous waltzes (Op. 12, No. 2 and Op. 38, No. 7). The melody reveals much chromaticism, which played a significant role in Grieg's music.

Example 2-61. "Walzer" Op. 47, No. 1, mm. 1-9

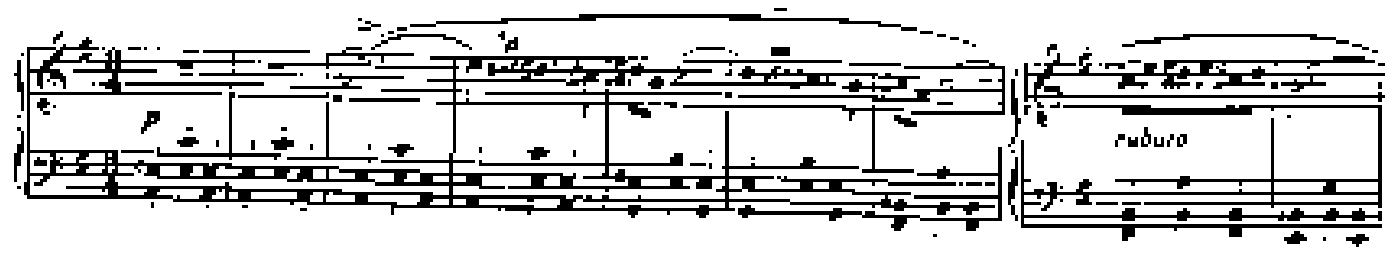


We find large E-minor tonic rolled chords emphasized in the middle section and these are also used to end each section.

Example 2-62. "Walzer" Op. 47, No. 1, mm. 39-42

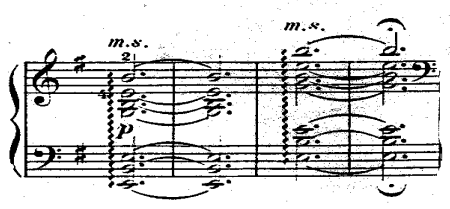

The other unique feature is a set of four-bar trills, used only in this Op. 47, No. 1. Example 2-63. "Walzer" Op. 47, No. 1, mm. 69-72

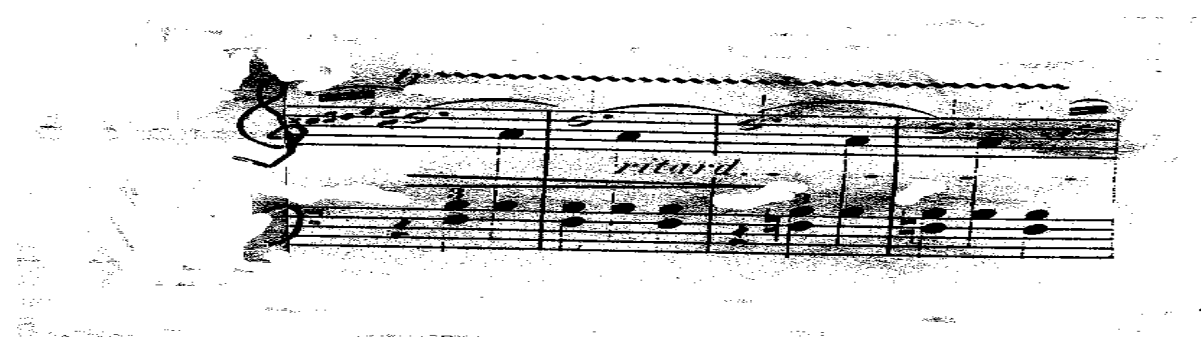

The last waltz is Op. 68, No. 6, titled "Valse mélancolique." This waltz has a fivebar introduction whose rhythmic motives recur as a melody in the bass of the middle section. 
Example 2-64. "Valse mélancolique" Op. 68, No. 6 mm. 1-5 and mm. 38-41

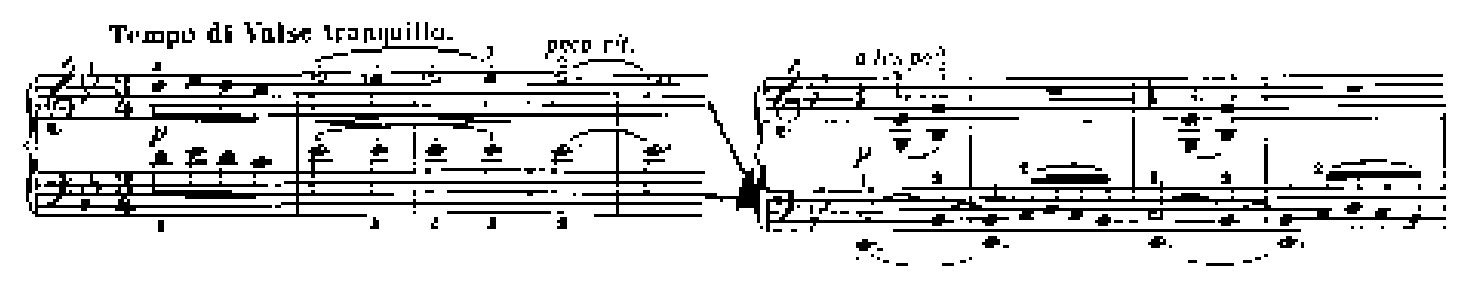

Only in this waltz, Op. 68, No. 6, we can find a melody in chordal style. This waltz is also the longest of Grieg's four waltzes.

Example 2-65. "Valse mélancolique" Op. 68, No. 6, mm. 54-57

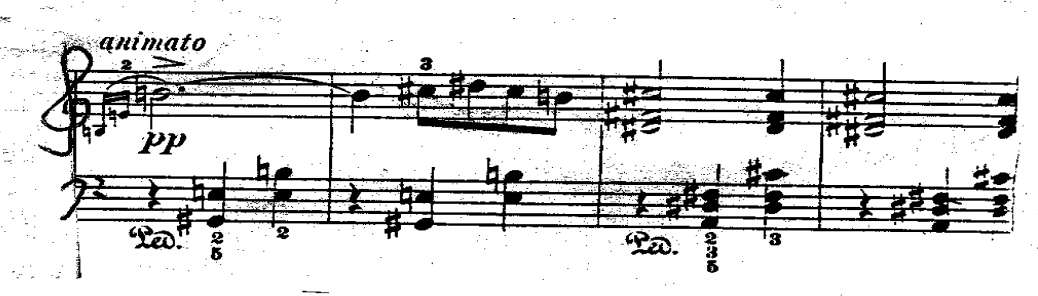


In conclusion, the rest of this chapter will summarize formal structure, melody, harmony, rhythm and accompaniment styles in nineteenth-century piano waltzes, focusing on Schubert, Brahms, Chopin, Liszt and a few others.

In formal structure, ternary architecture is the most dominant feature of nineteenth-century waltzes. We find this form in waltzes by Schubert, Brahms, and Chopin, and also in Schumann's waltzes from Carnaval. However, Weber and Liszt departed from the ABA formal structure. Both Weber's "Invitation to the Dance" and Liszt's first "Mephisto Waltz" include programmatic content as well.

Melodies of early nineteenth-century piano waltzes tend to be elegantly lyrical, singable, and graceful. Usually the melody appears in the upper notes, but sometimes it occurs in the bass or in inner voices. In Weber's "Invitation to the Dance," a "conversational" effect between man and woman occurs through tessitura. We find the melody in the bass in the middle section (mm. 128-131), after which the soprano imitates the melody from the previous bass part.

In Brahms' Waltzes, inner-voice melody occurs in Waltzes No. 3 and No. 5. In Waltz No. 16, the beginning melody appears later as invertible counterpoint in the tenor, mm. 9-16.

Liszt mainly used two contrasting themes in his first "Mephisto Waltz." The first theme, in mm. 111-117, is a marcato melody in fast tempo. Contrastingly, the second theme is a tender legato passage, played a little slower than the first melody.

Normally, nineteenth-century waltzes employ tonal harmony, with major and minor scales. In some waltzes by Schubert, Chopin, Brahms and Grieg, the second (B) section shows a parallel-key relationship. For example, in Chopin's E minor waltz, Op. posthumous, the A section is in $\mathrm{E}$ minor and the $\mathrm{B}$ section is in $\mathrm{E}$ major.

In Brahms' Waltzes, Waltz No. 9 begins in $\mathrm{d}$ minor but ends, unusually, with $\mathrm{V}$ of $\mathrm{D}$ major. This A-major chord ( $\mathrm{V}$ of $\mathrm{D}$ major) resolves in Waltz No. 10, which begins with 
a D-major chord, reinforcing the conclusion that Brahms intended these pieces to be played as a set. In Brahms' Waltzes, a dominant-tonic relationship also occurs between waltz No. 11 in B major and No. 12 in E major. In addition, waltzes No. 13 and No. 14 are in relative keys (B major in Waltz No. 13 and G-sharp minor in Waltz No.14).

Coinciding with the remote key change from D-flat to $\mathrm{C}$ major in Weber's "Invitation to the Dance," we see that the dynamics simultaneously change from fortissimo to pianissimo, and this is the softest level of the entire piece. It seems that Weber tried to emphasize these keys and dynamics by placing them in the middle section of the piece.

Both Chopin and Liszt used chromatic passages. In Chopin's waltz in E minor Op. posthumous, during the second theme of the A section, every downbeat in each hand shows a chromatic descending scale:

R.H.: C-B-B flat-A-G-F sharp

L.H.: E-D sharp-D-C sharp-C-B.

Example 2-66. Chopin "Waltz in E minor," mm. 25-31

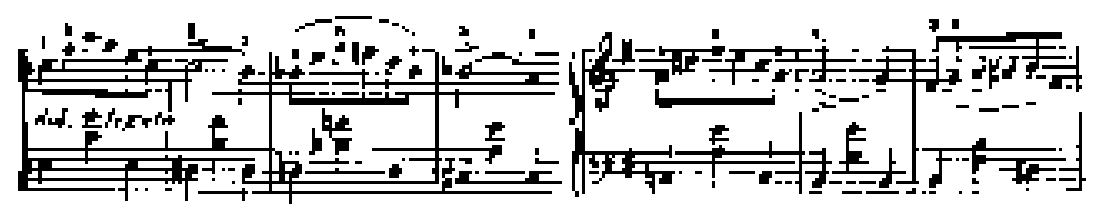

Grieg's "Lyric Piece," Op. 12, No. 2 employs an alternation of A major and A minor tonalities.

Both Schubert's and Weber's waltzes are quite straightforward in their rhythm. In other words, we find no complex rhythms. By contrast, Chopin sometimes uses cross rhythms like two-against-three.

Like Chopin, Brahms also used various rhythms. Consistent rhythmic figures appear in Waltzes Nos. 2, 8, and 9. Waltzes No. 2 and No. 8 include dotted rhythms throughout. In Waltz No. 2, the accompaniment demonstrates syncopated rhythms throughout. Cross rhythms occur at the beginning of Waltz No. 16. The "sigh figure" 
rhythm in Waltz No. 9 makes it easy to accent the third beat, because the higher melody on the third beats connects to the lower notes on beat one.

The familiar "waltz bass" ("oom-pah-pah") is the dominant accompaniment style. Weber, Chopin, and Schubert wrote mostly in this "oom-pah-pah" style. However, in Brahms' Waltzes Op. 39, we see more variety in accompaniment styles, compared to the previous three composers. First, we find syncopated rhythmic accompaniment in Waltz No. 2. Broken tenths (b-d) and rolled chords occur at the end of Waltz No. 4. The broken octaves in low ranges provide rich sound typical of Brahms.

Liszt hardly ever employs "oom-pah-pah" accompaniments in his first "Mephisto Waltz," perhaps because this simple style is less consistent with this work's bravura manner. 


\section{Chapter Three}

\section{Twentieth-Century Waltzes}

In the twentieth century, the waltz has been developing as an experimental piece. This section of the paper will discuss waltzes by Béla Bartók, Maurice Ravel, Sergei Prokofiev, Morton Gould, and the works in a collection entitled Waltzes by 25

Contemporary Composers. ${ }^{49}$ Also, it will include a list of other twentieth-century composers' waltzes.

\section{Béla Bartók (1881-1945)}

In 1908, Bartók wrote his "Bagatelles," Op. 6, a suite of fourteen short character pieces. According to the New Harvard Dictionary, the word "Bagatelle" indicates a short and unpretentious piece. ${ }^{50}$ Bagatelles are often presented in sets with contrasting tempos and modes. The pieces in Bartók's "Bagatelles" reveal characteristic sound colors, melodic and rhythmic invention, spareness of texture, symmetrical organization, precise articulation, dynamics and phrasing. ${ }^{51}$ Many of the composing styles in Op. 6 became an integral part of Bartók's later technique. Also, this piano music of 1908 shows the influences of folk sources, especially the peasant music of Hungary.

Of the fourteen "Bagatelles," the last one is a fast and sardonic waltz titled "Ma mie que dance...." Programmatically, this waltz describes the folk story of a girl who was forced to dance herself to death. ${ }^{52}$

This fourteenth Bagatelle divides into six sections:

Section A (mm. 1-17)

Section B (mm.18-36)

Section C (mm. 37-66)
Section D (mm. 67-150)

Section E (mm. 151-178)

Section E (mm. 179-218) $)^{53}$

Section A, mm. 1-8, begins with a traditional waltz accompaniment rhythm, alternating between a D major triad and a chromatically-altered dissonant chord. 
Example 3-1. Bartók "Valse" XIV, mm.9-12

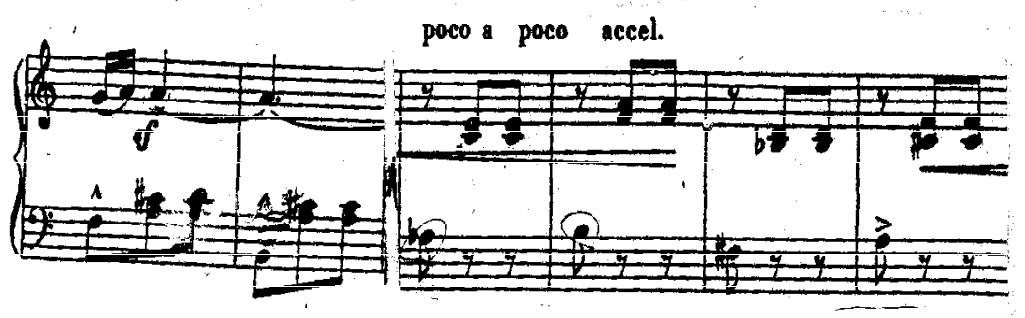

In section $\mathrm{B}$, two ostinato figures provide the main ideas.

Example 3-2. Bartók "Valse" XIV, mm. 22-25 and mm. 29-31

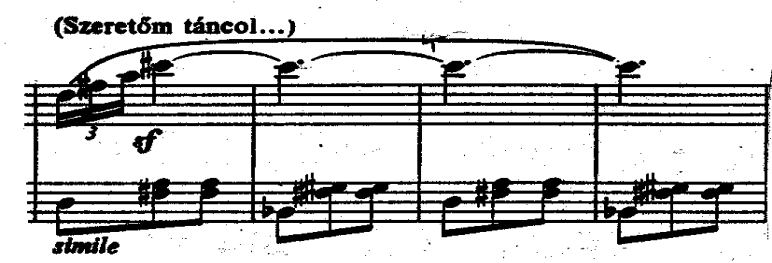

Section C starts with a long sustained A in the right hand, lasting for twenty beats. In mm. 45-65, the traditional waltz accompaniment gradually rises within a faster tempo ("poco a poco accelerando").

Examlpe 3-3. Bartók "Valse" XIV, mm. 37-38 and mm. 46-49

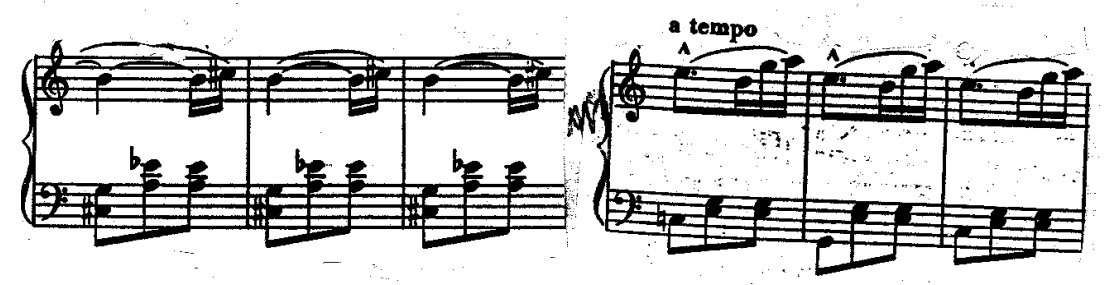

In mm. 59-65, we see rhythmic changes, compared to previous passages, and these lead toward section D. 
Example 3-4. Baretók "Valse" XIV, mm. 59-62

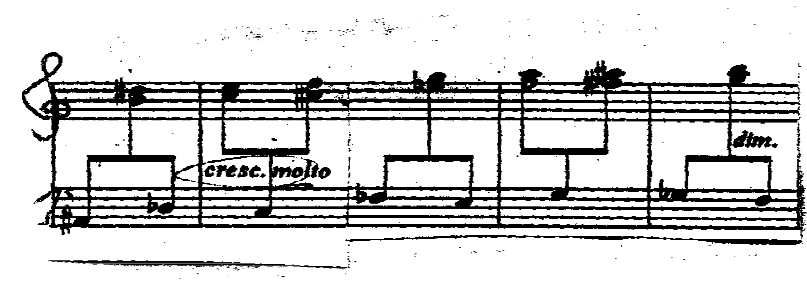

The $\mathrm{D}$ section is the longest segment and also the most active. In the $\mathrm{D}$ section, the main rhythmic motive plays an important role and it appears in many different ranges.

Example 3-5. Bartók "Valse" XIV, mm. 76-79 and mm. 92-94

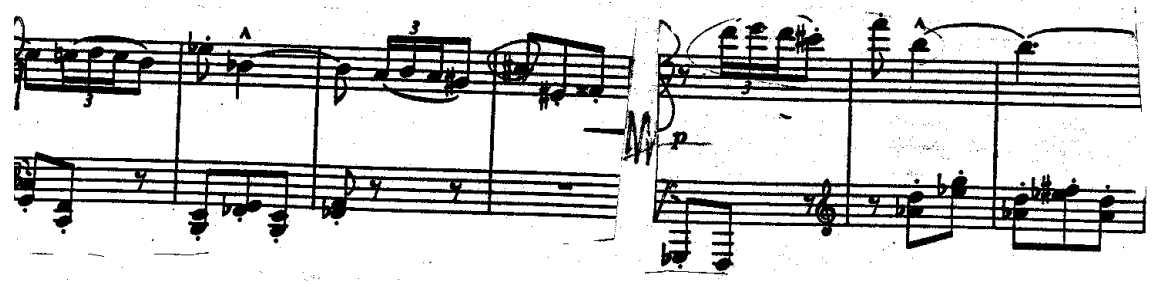

In mm. 127-142, the parallel-third thematic motive derives from mm. 114-116, and this leads to the final material, section $\mathrm{E}$.

Example 3-6. Batrók "Valse" XIV, mm. 127-130

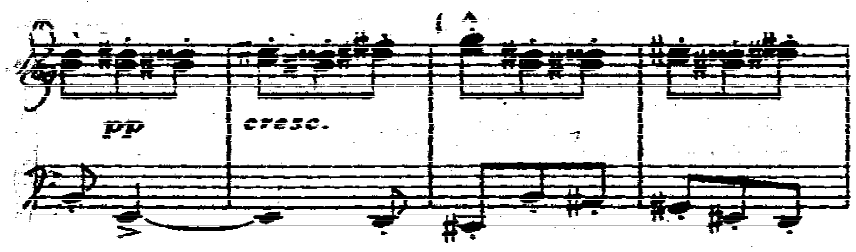

Also, in these thirds, we see contrasting dynamic ranges, from $f f$ (in mm. 135-142) to $p p$ (in mm. 143-150). 
Example 3-7. Bartók "Valse" XIV, mm. 135-136 and mm. 143-144

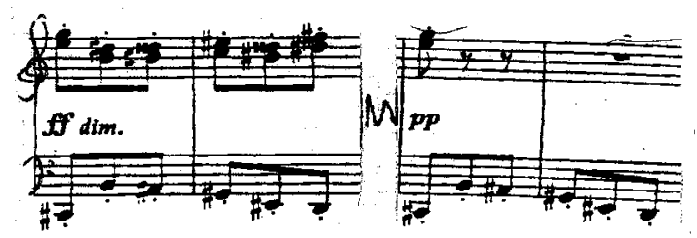

The E section contains mainly rhythmical sequential figures. These motives rise in range and increase in dynamics and rhythmic drive. In the high register, the repeated G-sharps in mm. 172-175 suggest screaming and mm. 176-178 help to set the return to the next $\mathrm{A}^{\prime}$ section.

The A' section is also a coda, where Bartók employs long trills in the melody instead of holding a single note as he had done previously.

Example 3-8. Bartók "Valse" XIV, mm.179-181 and m. 9

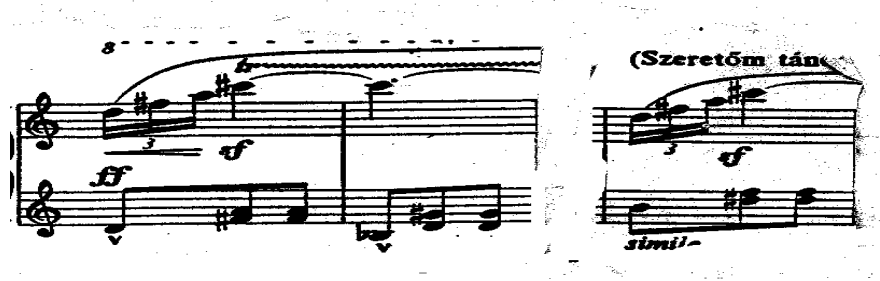

In mm. 198-208, Bartók uses no more trills in the thematic motives and these passages gradually die away. In mm. 209-217 we see a sudden burst of ascending D-seventh broken chords rising to a high C-sharp.

In Bartók's fourteenth Bagatelle, he indicates tempo changes very exactly. For example, he requires a specific metronome speed, such as $\quad=108$. In this waltz, Bartók used 
ostinato figures (in mm. 22-35), three-against-four (in m. 27) and hemiola (in m. 17, m. 59, and m. 83).

In the tonal structure of this piece, Bartók employed whole-tone scales (in mm. 29-36) and many third-relationships, both in the accompaniment parts and also in the melody, especially in section D.

Finally, Bartók's waltz is a very sectional piece and it shows frequent and abrupt changes of texture both within the sections and also between the sections.

\section{Sergei Prokofiev (1891-1953)}

Prokofiev wrote nine piano sonatas between 1907-1947. Out of the nine piano sonatas, numbers six through eight are known as the "War Sonatas." These are all big works in three movements, except Sonata No. 6, which has four movements. This is a huge and powerful work that suggests both biting fury and lyric elements. ${ }^{54}$

The Sixth Sonata, Op. 82 (1939-1940) was written during World War II after Prokofiev had returned to the USSR. ${ }^{55}$ In 1940, Prokofiev himself premiered the Sixth Sonata in a radio recital from Moscow and the sonata was later performed by Moscow pianist Svyatoslav Richter.

The third movement of Sonata No. 6, Op. 82, bears the marking "Tempo di Valser lentissimo." The character of this movement is similar to a lyrical nocturne in the rhythm of a slow waltz. The movement is in ABA form as follows:

Section A (mm. 1-41)

Section B (mm. 41-48)

Section A’ (mm. 86-123)

The main theme of the A section appears in mm. 1-4. The rich chords of this theme extend from mm. 1-12 and these thematic materials appear four times in the A 
section.

Example 3-9. Prokofiev Piano Sonata No. 6, third movement, mm. 1-4

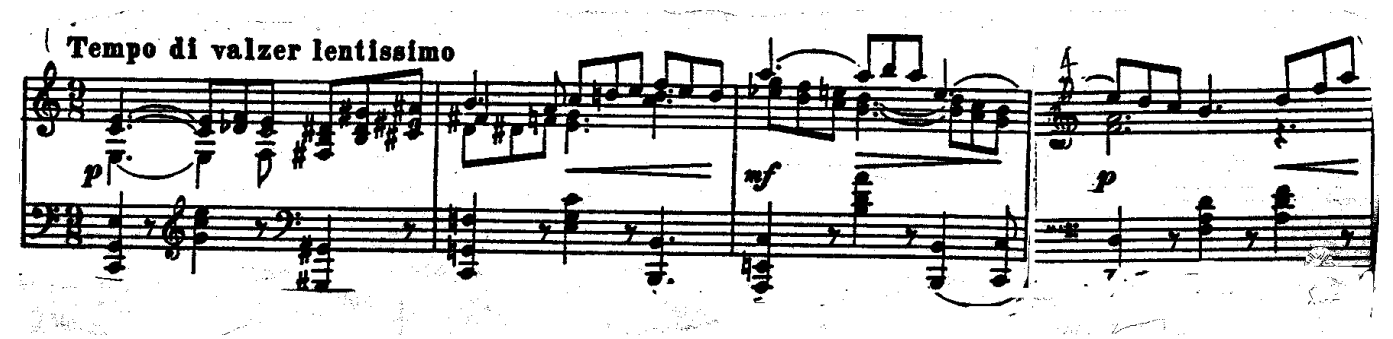

Abrupt key changes appear in this section:

C Major (mm. 1-19)

A-flat Major (mm. 20-28)

D Major (mm. 29-36)

A-flat Major (mm. 37-40)

In contrast to the slow waltz rhythm of the A section, the B section demonstrates terrifying clashes of sound, marked Poco Piú Animato. The key changes twice in the B section, from A-flat to $\mathrm{C}$. Unlike the repeated rhythmic pattern of the A section, the B section shows various rhythms, including meter changes, alternating two-four and threefour in mm. 43-44, mm. 68-69 and mm. 77-81.

The last A' section shows a bigger style than the previous A section, with chords, chordal grace notes (m. 107), and the dynamic level increased to $f f$. 
Example 3-10. Prokofiev's Piano Sonata No. 6, third movement, mm. 107-109

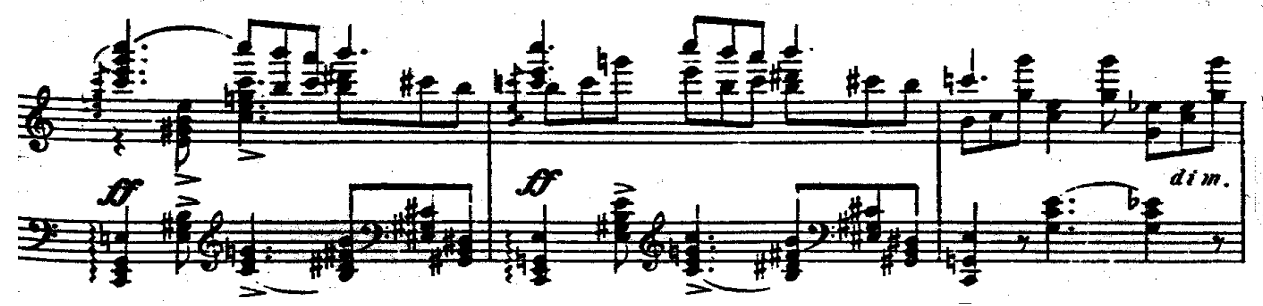

Prokofiev may have been the first major composer since Haydn to include a waltz as a movement within a piano sonata. Prokofiev produced several other waltzes for solo piano, mostly individual pieces transcribed from his orchestral pieces and other composers' works. These additional waltzes include the following:

Op. 32: Four Pieces

No. 4, "Waltz"56

Op. 95: Three Pieces for Piano from the ballet Cinderella

No. 3, "Slow Waltz"

Op. 96: Ten Pieces for Piano from the operas War and Peace and Lermontov

No. 1, "Waltz" and No. 3, "Mephisto Waltz" from Lermontov

Op. 102: Six Pieces for Piano from the ballet Cinderella

No. 1, "Waltz," and No. 4, "Waltz"

Transcriptions of Works by Other Composers

Waltzes by Schubert-Prokofiev ${ }^{57}$

\section{Maurice Ravel (1875-1937)}

Ravel's Valses nobles et sentimentales (1911) consists of seven waltzes and an epilogue. The opening bears the additional subtitle "Adélaïde." Ravel orchestrated these waltzes to accompany a ballet, Adélaïde ou le langage des fleurs, on a scenario written by the composer and produced during Mlle. Trouhanova's season of ballets at the Châtelet on 
April 22, 1912. ${ }^{58}$ The action takes place in the Paris salon of a courtesan named Adélaïde about 1820. There are seven scenes and an epilogue, as in the original.

Scene 1. While the couples are waltzing or engaged in tender conversation Adélaïde comes and goes. She is wearing a tuberose, the symbol of sensual pleasure.

Scene 2. Enter Lorédan in melancholy mood. He offers her a buttercup, and the exchange of flowers that follows symbolizes Adélaïde's coquetry and her suitor's love for her.

Scene 3. Adélaïde sees from the flower offered her that Lorédan's love for her is sincere, but the marguerite she gave to Lorédan tells him that his love is not returned. Lorédan tries a second time, and this time the reply is favourable.

Scene 4. The lovers dance together affectionately, but are interrupted by the entrance of The Duke.

Scene 5. The Duke presents Adélaïde with a sunflower (a symbol of empty riches) and a diamond necklace, which she puts on.

Scene. 6 Lorédan in despair presses his suit, but is repulsed coquettishly.

Scene. 7 The Duke begs Adélaïde to give him the last waltz. She refuses, and goes in search of Lorédan, who strikes an attitude of tragic despair. Finally he yields to her insistence and they go off together.

Epilogue. The guests retire. The Duke, hoping to be asked to stay, receives from Adélaïde's hands a branch of acacia (symbol of Platonic love) and departs in high dudgeon. Lorèdan approaches looking very sad. Adélaïde gives him a poppy (an invitation to forget), but he rejects it and goes off, biding her farewell for ever. Adélaïde goes to the window and breathes the scent of the tuberose. Suddenly Lorédan appears on her balcony in a state of agitation, falls on his knees and presses a pistol to his head. But Adélaïde smilingly produces from her corsage a red rose and falls into his arms

At the top of the score Ravel placed a quotation by Henri de Régniers: "...le plaisir délicieux et toujours nouveau d'une occupation inutiles" ("the delicious and ever- new pleasure of a useless occupation"). This quotation provides insight into Ravel's mood and intention at that time.

This work seems influenced by Schubert's waltzes, in part through reference to the titles of two waltz sets by Schubert, Valses nobles ( D. 969) and Valses sentimentales (D. 779).

The premiere of Valses nobles et sentimentales occurred on May 9, 1911, at a concert "sans noms d'auteurs" of the Société Musical Indépendante, at which the audience members were invited to guess the identity of the composer. The Valses were played by pianist Louis Aubert, to whom they are dedicated. ${ }^{60}$

Now let us look at each of the Valses in turn. 


\section{Waltz No. 1: Modéré tres franc}

The first opening is vigorous, with clusters of chords in clashing major ninths. The rhythmic patterns of the first half closely resemble the opening of Schubert's waltz D. 365, No. 33 (see examples 3-11 and 3-12 below). ${ }^{61}$

Example 3-11. Ravel Valses nobles et sentimentales, No. 1, mm. 1-4

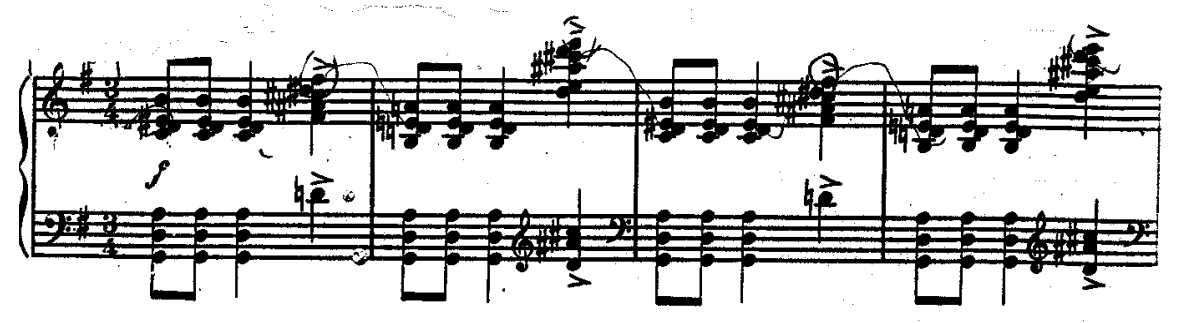

Example 3-12. Schubert Sechsunddreissig Originaltänze, D. 365, No. 33, mm. 1-4

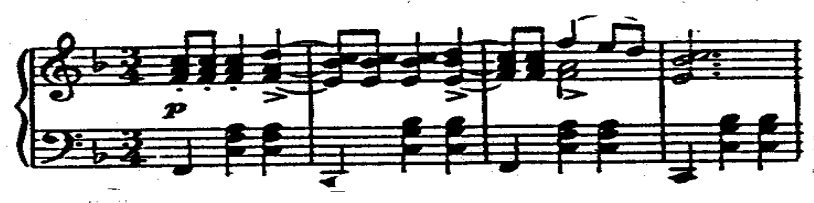

Ravel employs ABA form for Waltz No. 1. As Example 3-13 reveals, the B section contrasts with the previous A section both in its soft and gentle character and also in its texture, which is thin compared to the chordal writing in section A.

Example 3-13. Ravel Valses nobles et sentimentales, No. 1, mm. 33-35

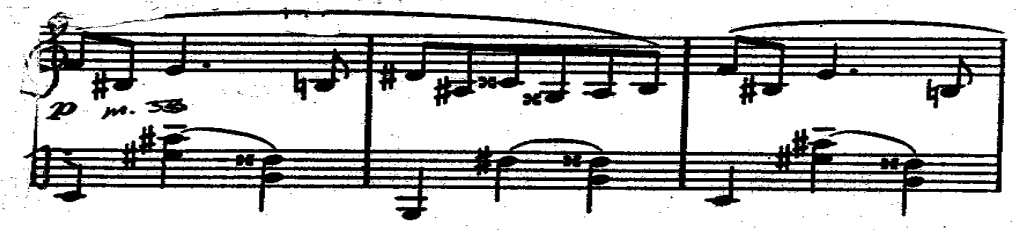

In measures 45-48, the rhythmic patterns come from the beginning of the waltz, repeated in the A' section. We see chromatic ascents in mm. 50-51 and in mm. 57-60. 
The repeated ninth chords of $\mathrm{m} .77$ signal a close in G Major.

Example 3-14. Ravel Valses nobles et sentimentales, No. 1, mm. 77-79

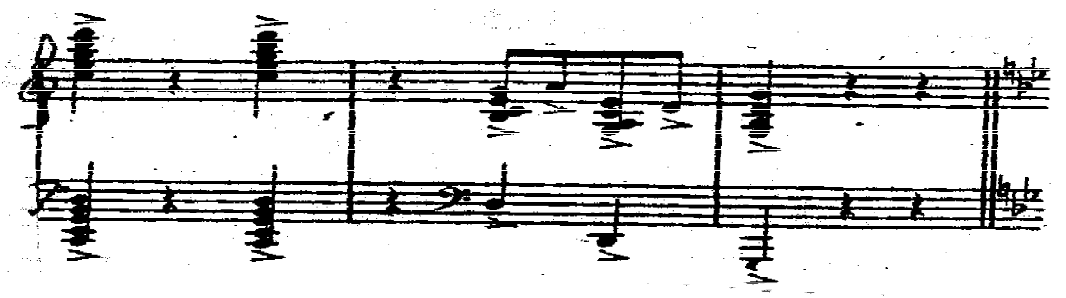

Waltz No. 2: Assez lent avec une expression intense

Waltz No. 2 starts with a seven-bar introduction and displays a sentimental character. The main melody appears in mm. 9-17.

Example 3-15. Ravel Valses nobles et sentimentales No. 2, mm. 9-12

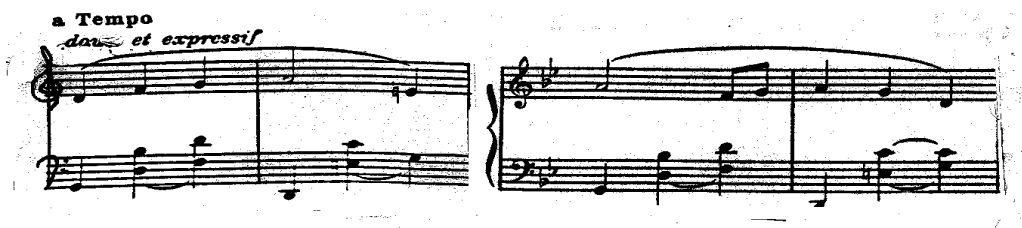

The grace notes in the repetition of the theme during mm. 13-15 convey a more delicate mood (see Example 3-16). The second theme (see Example 3-17 below) appears in $\mathrm{mm}$. 26-29 using grace notes and a repetition of $\mathrm{C}^{3}$ in the melody. Example 3-16. Ravel Valses nobles et sentimentales No. 2, mm. 13-15

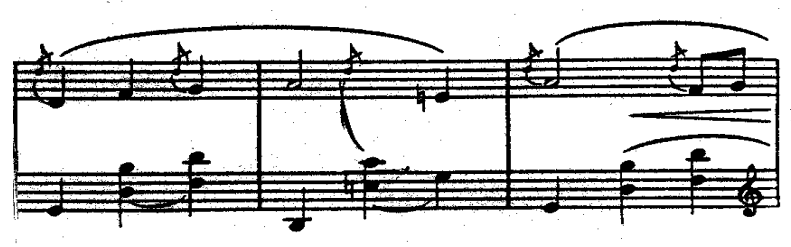


Example 3-17. Ravel Valses nobles et sentimentales No. 2, mm. 27-29

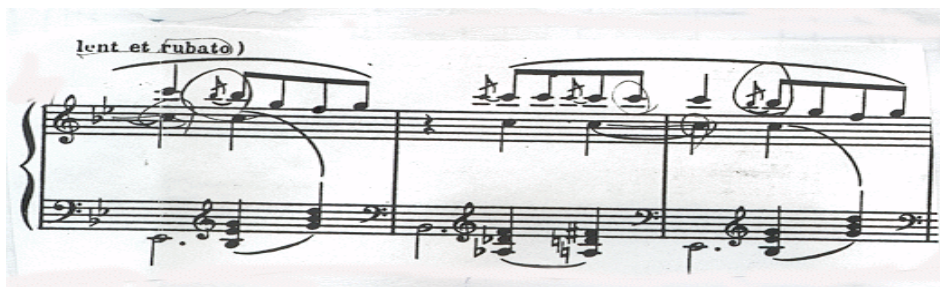

This theme comes to a cadence in mm. 30-33. The binary form produced up to this point is repeated until the end of this waltz. We see a reprise of this theme in mm. 42-45, with the melody in an inner voice rather than in the top notes. Thus, the formal structure of this waltz is a double ABA form:

Introduction, mm. 1-7,

Section A, mm. 8-25,

Section B, mm. 26-33,

Introduction, mm. 34-41,

Section A, mm. 42-57,

Section B, 58-65.

Waltz No. 3: Modéré

The melody of this E-minor waltz is light in character. We also see rhythmic displacement over the bar lines in mm. 5-6 and again in mm. 13-14. Waltz No. 3 also reveals an $\mathrm{ABA}$ structure.

Example 3-18. Ravel Valses nobles et sentimentales No. 3, mm. 5-6 and mm. 13-14

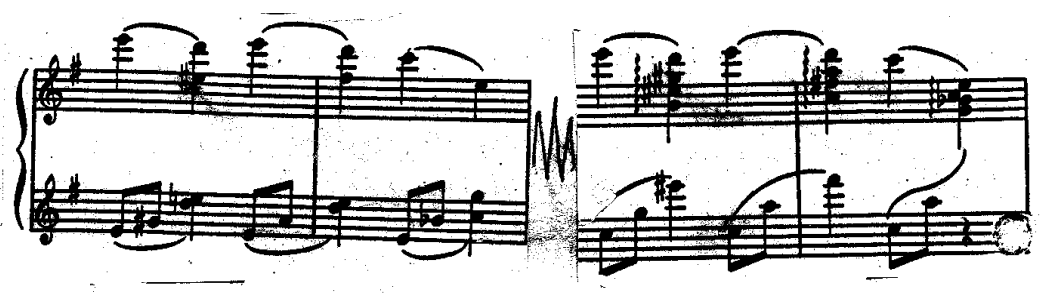


In the second section, mm. 33-56, the accompaniment uses pedal points on

F-sharp and on B. The reprise section starts in $\mathrm{mm}$. 57-72, G major rather than e minor. As Example 3-19 reveals, measures 71-72 connect smoothly to Waltz No. 4.

Example 3-19. Ravel Valses nobles et sentimentales No. 3, mm. 71-72

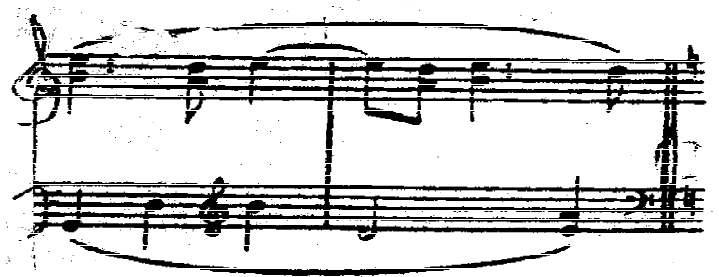

Waltz No. 4:

Assez anime

The opening rhythmic figures derive from the last two measures of Waltz

No. 3 (see Example 3-20 below).

Example 3-20. Ravel Valses nobles et sentimentales No. 4, mm. 1-2

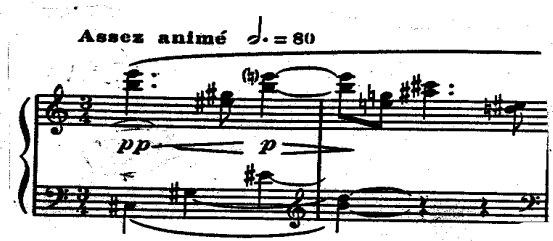

Ravel employs an ABA formal structure for Waltz No. 4. The B section of this waltz has the only repeat sign within the entire set of eight waltzes. The crescendos and decrescendos contribute throughout this entire waltz to an effective swaying character. Waltz No. 5: Presque lent dans un sentiment intime

The fifth waltz is in E major and demonstrates ABA form. The $\mathrm{B}$ section reveals a dreamy, flowing character, within $p p$ and ppp, as shown in Example 3-21. 
Example 3-21. Ravel Valses nobles et sentimentales No. 5, mm. 17-18 and mm. 21-2

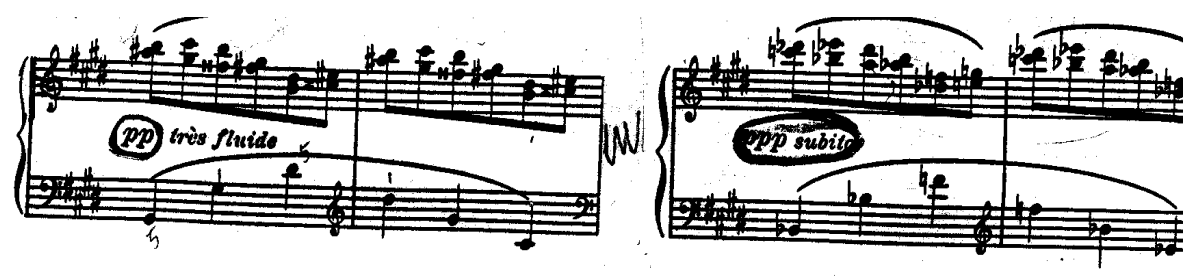

Measures 19-20 and mm. 23-24 (see Example 3-22) show cross rhythms that resemble Chopin's Waltz in A-flat, Op. 42.

Example 3-22. Ravel Valses nobles et sentimentales No. 5, mm. 19-20 and mm.23-24

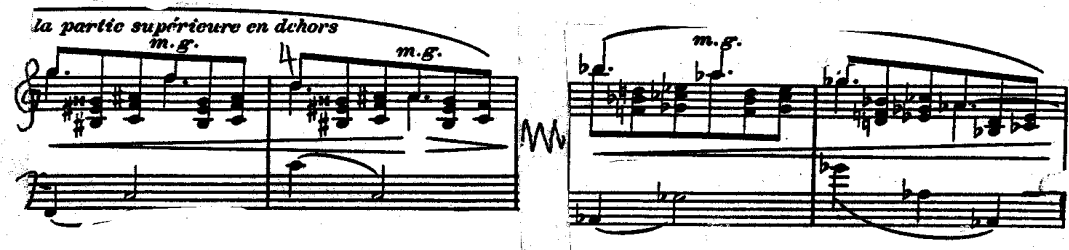

Example 3-23. Chopin Waltz Op. 42, mm. 9-12

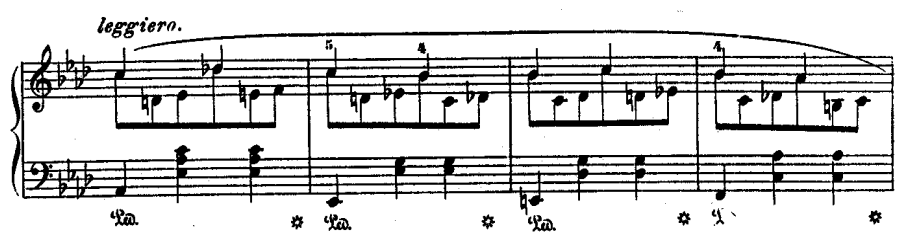

Waltz No. 6: Vif

Waltz No. 6, in the key of C major, shows a lilting character. Like No. 5, it also reveals $\mathrm{ABA}$ form. In section $\mathrm{A}$ we see rhythmic complexity as the hands combine duple and triple divisions of the bar. 
Example 3-24. Ravel Valses nobles et sentimentales No. 6, mm. 1-4

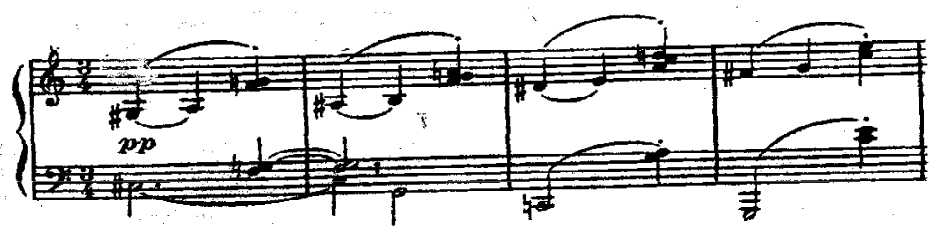

In mm. 37-44 (see Example 3-24) we see chromatic ascent in the right hand. We also observe a long dramatic crescendo to the peak of this piece, followed by a dying away to a quiet ending in $\mathrm{C}$ major.

Example 3-25. Ravel Valses nobles et sentimentales No.6, mm. 37-40

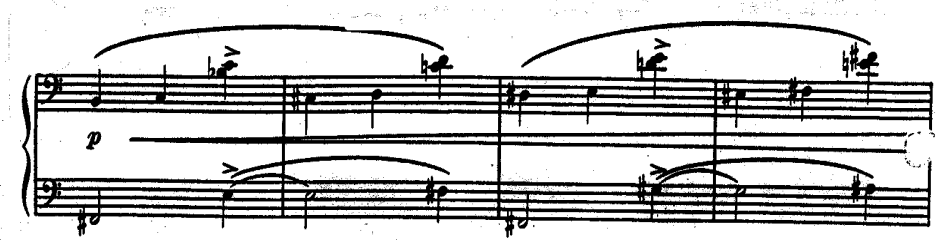

\section{Waltz No. 7: Moins vif}

This is the longest waltz of the entire set. Like the others, it is also in ABA form. The introduction extends to measure 18 and the thematic material derives from a fragment of the previous waltz.

Example 3-26. Ravel Valses nobles et sentimentales Thematic Comparison of Waltz No. 6 mm. 60-61 and Waltz No. 7 mm. 1-2

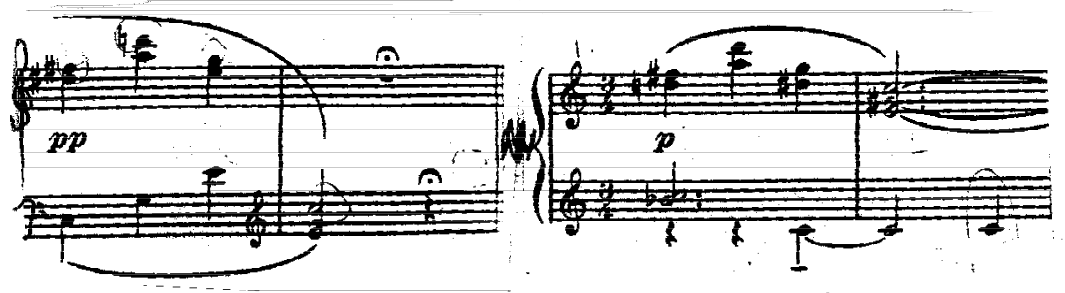


In section A, Ravel seems to be notating the rhythmic hesitation of a Viennese waltz (see Example 3-27).

Example 3-27. Ravel Valses nobles et sentimentales No. 7 mm. 19-20

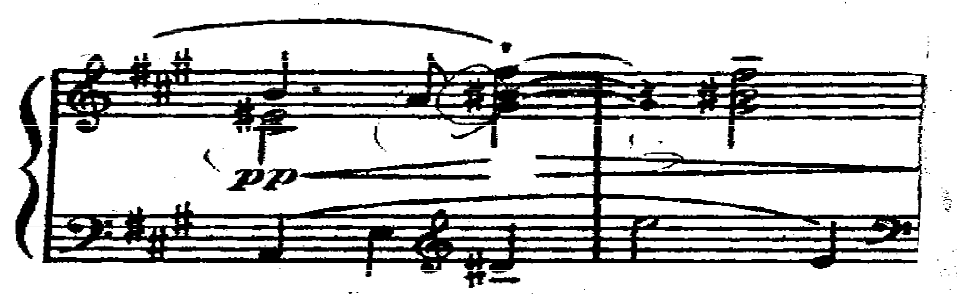

The actual dance begins in $\mathrm{mm} .17$ to 66 . The three-against-two rhythm appears in mm. 27-28. The second theme in the A section occurs in mm. 39 to 66 .

Example 3-28. Ravel Valses nobles et sentimentales No. 7, mm.39-40 (second theme)

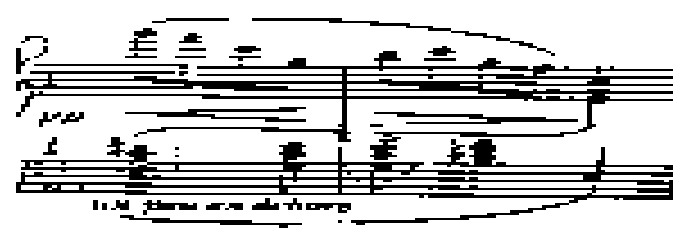

The vague, faint melody in mm. 39-50 seems to come from far away. During mm. 39 to 66, Ravel makes a dramatic gesture which leads to a big climax in measures 59-66. The rhythmic patterns in measures 39-42 appear in inverted form between melody and accompaniment in measures 47-50. 
Example 3-29. Ravel Valses nobles et sentimentales No. 7, mm. 41-42 and mm. 47-48, showing inversion.
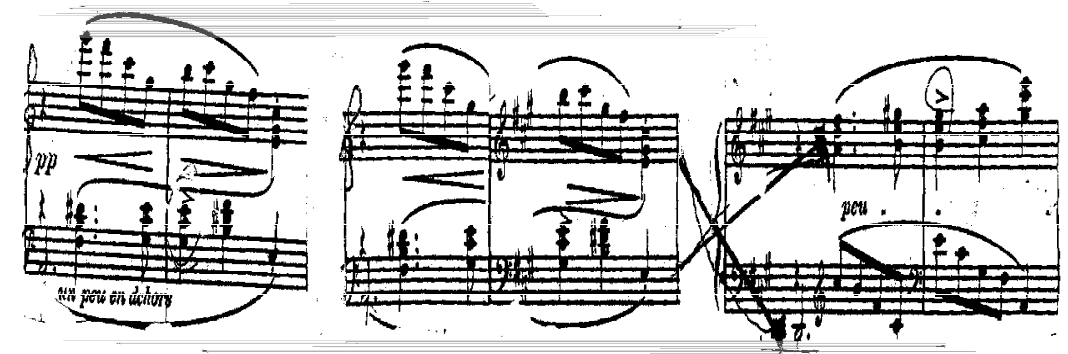

Also, in measures 30-66, the gradually increasing dynamics, from $p p$ to $f f$, are an important element leading to the peak in $\mathrm{m}$. 59. The ascending right-hand ornamentation in measures 55-57 suggests the gliding character of the waltz, with some emphasis on the second beat.

Example 3-30. Ravel Valses nobles et sentimentales No. 7, mm. 54-59

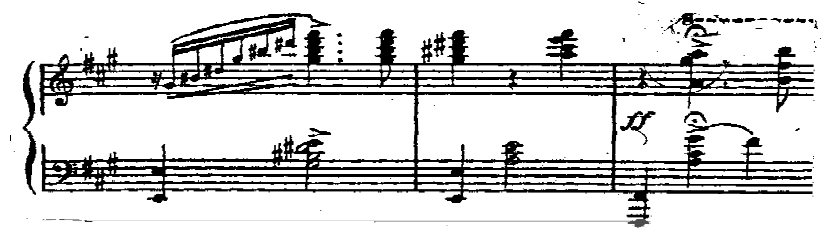

In the B section, three-against-two rhythms appear. Like those of Waltz No. 5 rhythmic figures resemble Chopin's Waltz in A-flat major, Op. 42. 
Example 3-31. Ravel Valses nobles et sentimentales No. 7, mm. 67-68 and

Chopin's Op. 42, mm. 9-10
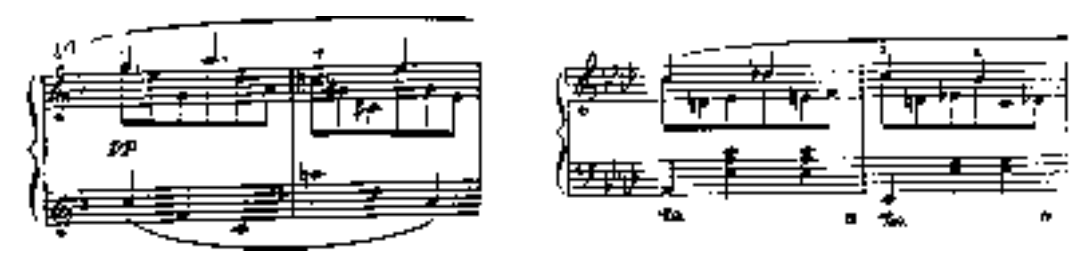

After the B section, Ravel repeats the A section exactly.

\section{Waltz No: 8 Épilogue (Lent)}

Waltz No. 8 recalls fragments of all of the preceding waltzes, except for waltz No. 5 , revealing a cyclic form.

The accompaniment figures in the left hand employ low pedal notes and, in mm. 46-74, a bass $\mathrm{G}$ appears throughout.

Example 3-32. Ravel Valses nobles et sentimentale No. $8 \mathrm{~mm} .52-54$

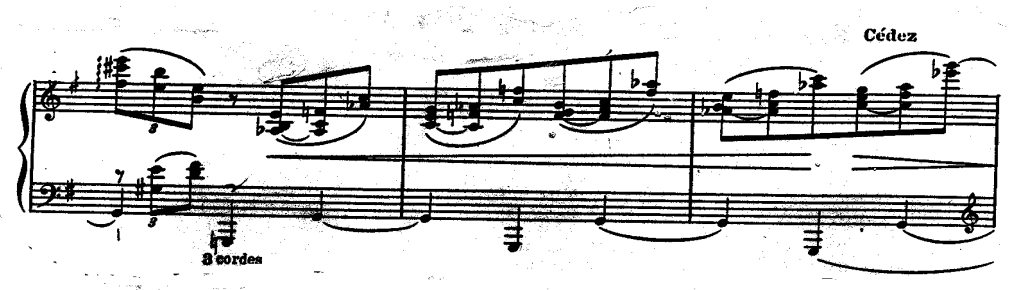

The low $\mathrm{G}$ sustained pedal points give an effect of blurred images and an impressionistic character throughout Waltz No. 8. The coda extends from mm. 62-74, and the melody in mm. 67-71 of the coda derives from mm. 42-44 of Waltz No. 2. 
Example 3-33. Ravel Valses nobles et sentimentales No. 8 mm. 67-69 and Waltz

No. $2 \mathrm{~mm} .42-44$
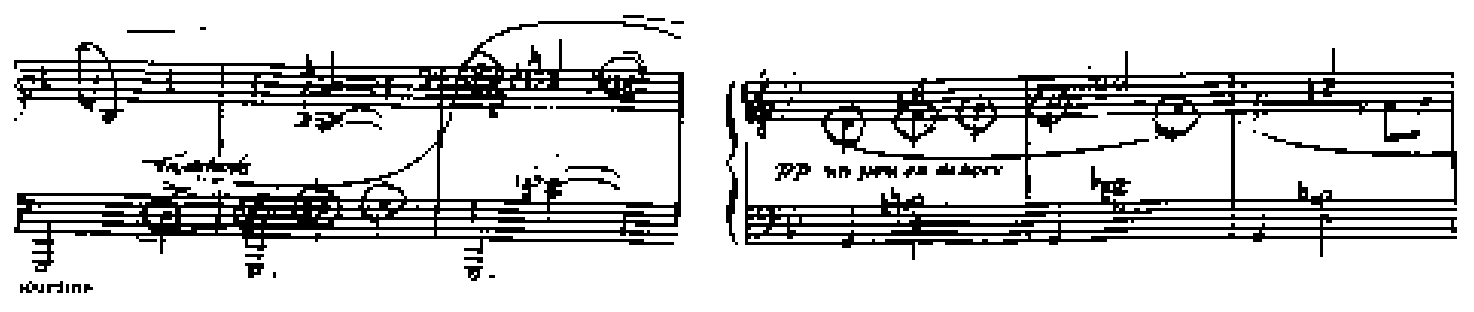

This last waltz and with it the entire set, ends in G major.

Example 3-34. Ravel Valses nobles et sentimentales No. 8, mm. 70-74

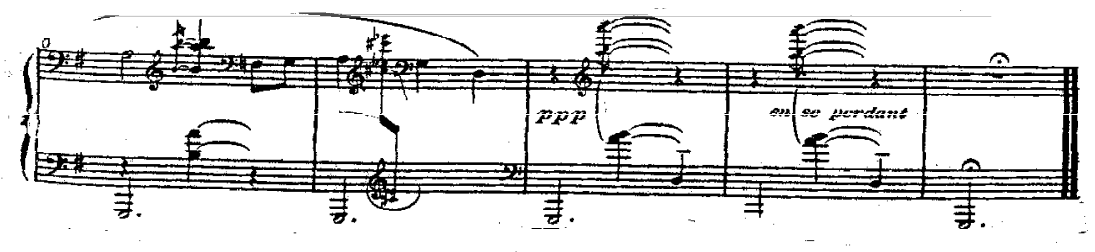

Ravel's Valses nobles et sentimentales are often delicate and always French. The ABA formal structure dominates each waltz. Tonally, Ravel used major and minor keys, ninth chords and chromatic passages. This is also a cyclic work because Waltz No. 8 includes fragments of the previous waltzes.

In addition to the Valses nobles et sentimentales, Ravel made an arrangement for solo piano of the orchestral work La Valse that provides a virtuoso, impressionistic interpretation of the Viennese waltz style. ${ }^{62}$

Now we turn our attention to Waltzes by 25 Contemporary Composers, a collection of recent contributions to this genre. ${ }^{63}$ These 25 waltzes show various characteristics of rhythms, meter, key, 
ornamentation, pedal marks, and other features of twentieth-century waltzes. Some reveal rather simple writing styles.

However, some of these waltzes show very complex or changing rhythms. Thus, it is often hard to find regular rhythmic phrases, making actual dancing to these pieces completely impossible. In addition, the frequently changing meters are the most dominant element of difference, compared to the nineteenth-century waltzes we have already discussed.

Most of the waltzes in this collection use traditional three-four time (or three-eight time), but six-eight and five-eight also appear. Milton Babbitt's "Minute Waltz" reveals a complicated $3 / 4 \pm 1 / 8$ meter. The basic rhythmic unit of this waltz is the eighth note; thus, in three-four time, we see six beats in each measure. But Babbitt adds an eighth value $(+1 / 8)$ to some measures (7/8) and subtracts an eighth (-1/8) from others (5/8).

Example 3-35. Babbitt "Minute Waltz," mm. 1-2 and m. 4
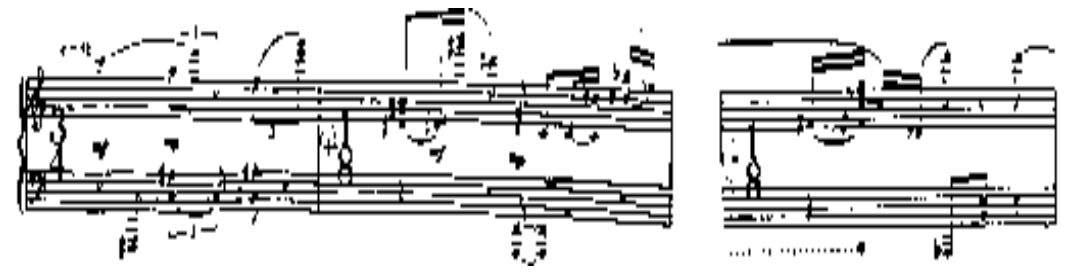

The other example in which almost every measure contains a new meter is "A Wedding Waltz," by Gerald Busby.

Example 3-36. Busby's "A Wedding Waltz," mm. 1-4

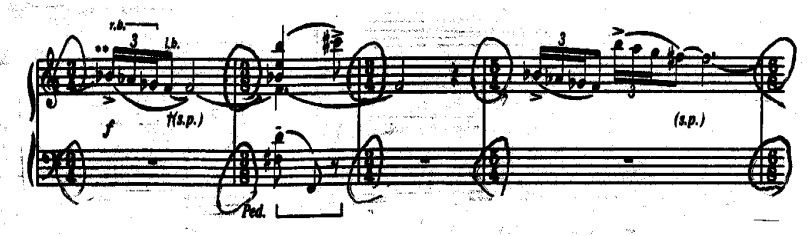

Most of the waltzes in 25 Waltzes are not tonal, but a few do use traditional keys. Among the tonal waltzes is Virgil Thomson's short "For a Happy Occasion," which is in $\mathrm{G}$ major, with a simple, hopping, staccato melody. The other tonal waltzes include Alden 
Ashforth's "Sentimental Waltz" (E-flat minor), and Lou Harrison's "A Waltz For Evelyn Hinrichsen," which uses Phrygian mode.

Example 3-37. Harrison's "A Waltz For Evelyn Hinrichsen" (ending)

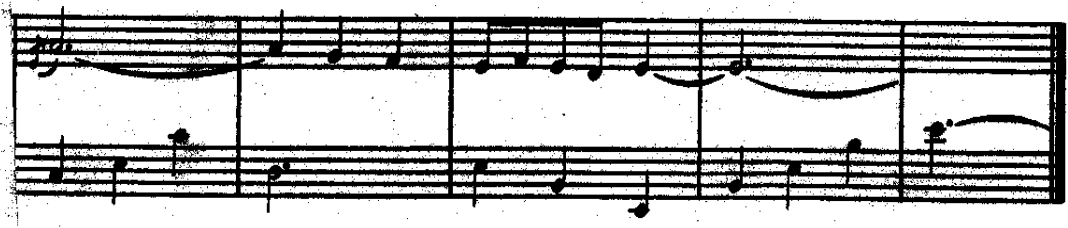

Grace notes and trills both figure prominently in nineteenth- and twentieth-century waltzes alike. In Lou Harrison's "A Waltz For Evelyn Hinrichsen," two types of ornamentations have important functions for this entire waltz. Trills appear in both Alan Stout's "Waltz" and Ivan Tcherepnin's "Valse Perpetuelle (The 45 R.P.M.)." In Alan Stout's "Waltz," double trills come in the middle and at the end of the piece.

Example 3-38. Stout's "Waltz" (double trills)

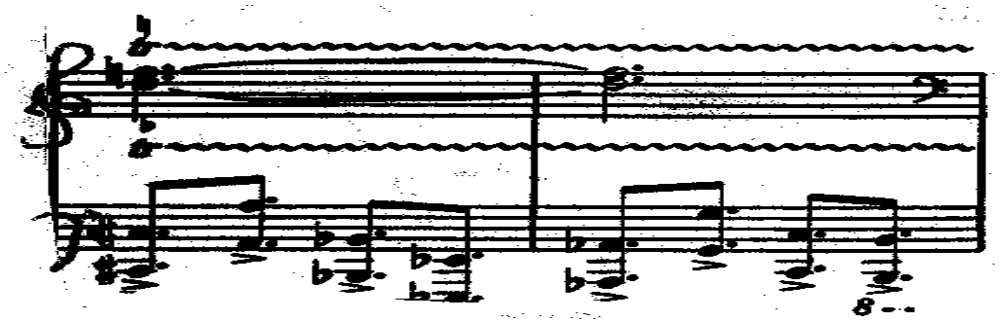

In the twentieth century, many composers add very exact pedal indications. Some waltzes in this collection bear such specific pedal marks, such as Ross Lee Finney's "Waltz" and Andrew Imbrie's "Waltz." The sostenuto pedal is required at the end of the Joseph Fennimore's "Titles Waltz: After Max Steiner" and also in Gerald Busby's "A Wedding Waltz." Alan Stout's "Waltz" shows specific pedal marks from the beginning to the end, including "pedal tremolo" near the end. 
Example 3-39. Stout's "Waltz" (tremolo pedal)

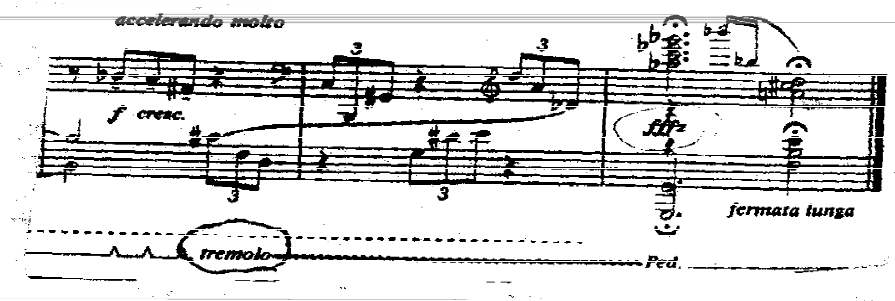

Compared to the complex rhythms and meters of several waltzes in this collection, simple melody and accompaniment styles appear in Virgil Thomson's "For A Happy Occasion," Robert Moran's "Waltz" (subtitled "In Memoriam Maurice Ravel") and Lou Harrison's "A Waltz For Evelyn Hinrichsen."

\section{Special Features of Twentieth-Century Waltzes}

In Waltzes by 25 Contemporary Composers, we find six different elements of twentieth-century compositional technique. First, we see non-traditional notations such as those which appear in Zygmunt Krauze's "Music Box Waltz." The "Music Box Waltz" has no key signatures, no meters, no bar lines and no double lines at the end of the piece. Both staffs are in treble clef and the pedal continues from the beginning to the end. The "Music Box Waltz" is in free style; especially at the end, the slur marks describe the echo of a music box.

Example 3-40. Krauze's "Music Box Waltz." Beginning

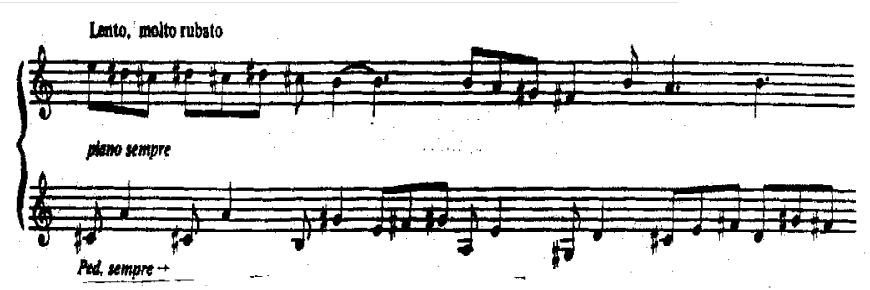

Also, in Ivan Tcherepnin's "Valse Perpetuelle," a notation at the end indicates "depress notes silently" and "lift pedal gradually" which reveals an echo effect on C. 
Example 3-41. Tcherepnin's "Valse Perpetuelle," (ending)

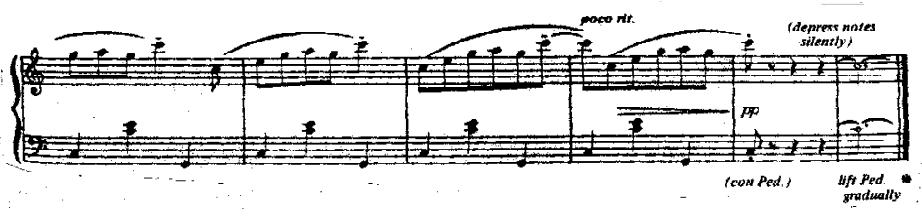

Second, in Francis Thorne's "A Love-Song Waltz," we find a cadenza which includes both arpeggios and scales. It is very free in style as well.

Example 3-42. Thorne's "A Lovesong Waltz," (cadenza)

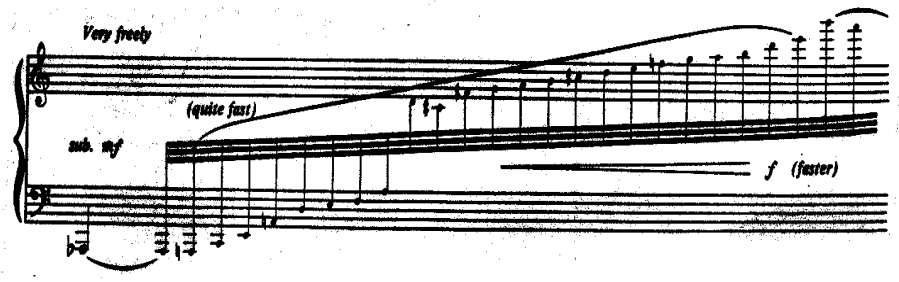

Third, tone-clusters appear in Ross Lee Finney's "Waltz." Tone-clusters occur as an accompaniment in the middle and at the end of the piece. In Joan Tower's "Red Garnet Waltz," chords with five sharps and flats appear at the end of the piec

Example 3-43. Finney's "Waltz," tone clusters

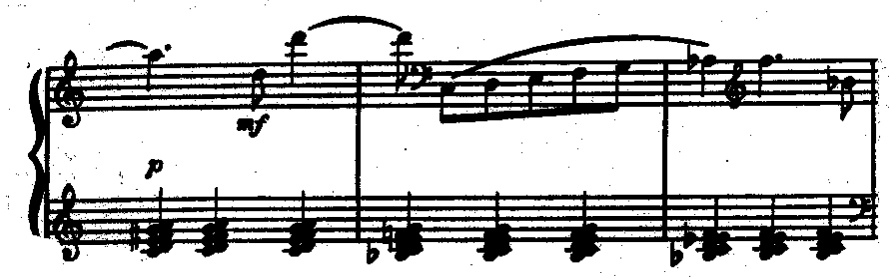


Example 3-44. Tower's "Red Garnet Waltz," tone clusters

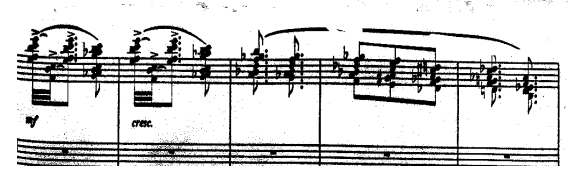

Fourth, an example of minimalism appears in Philip Glass's "Modern Love Waltz," with repeated fragments in almost every bar.

Example 3-45. Glass's "Modern Love Waltz." Minimalism

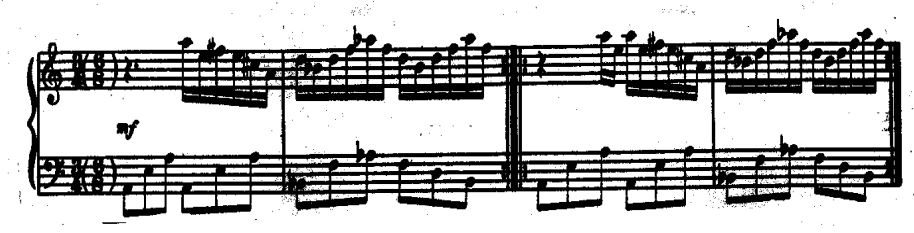

Fifth, an example of unusual form is chance operation in "49 Waltzes for the Five Boroughs" by John Cage. In this "musical" work, Cage writes descriptive text rather than musical notation.

Example 3-46. Cage's "49 Waltzes for the Five Boroughs"

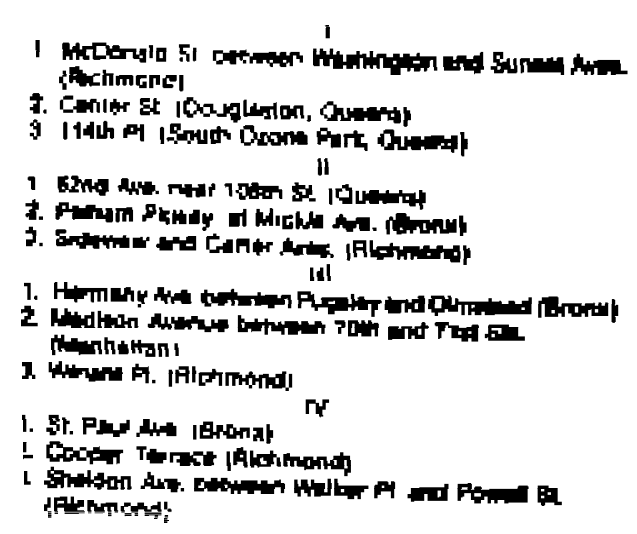

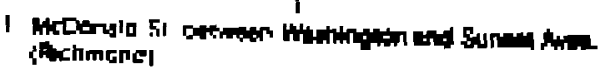

7. Eenilt at ion

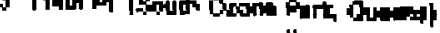

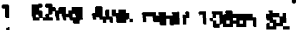

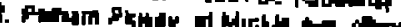

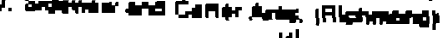

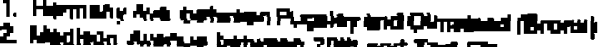

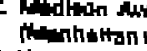

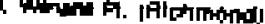

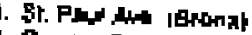

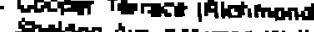
JFletwortis;

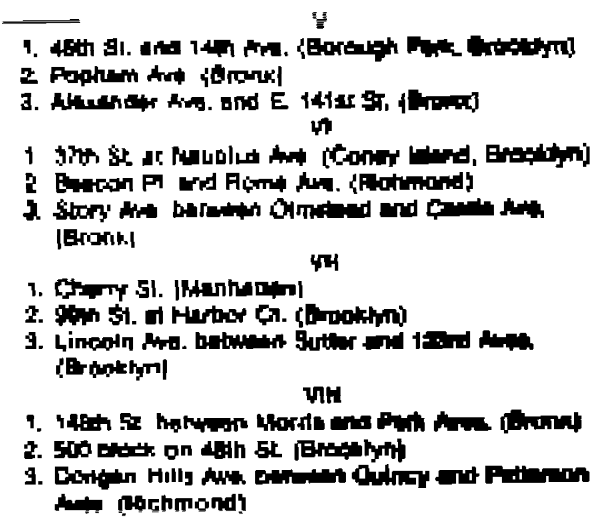


Sixth, Richard Felciano's "Two Hearts" requires performers to speak aloud during the piece.

\section{Example 3-47. Felciano's "Two Hearts" mm. 1-2}

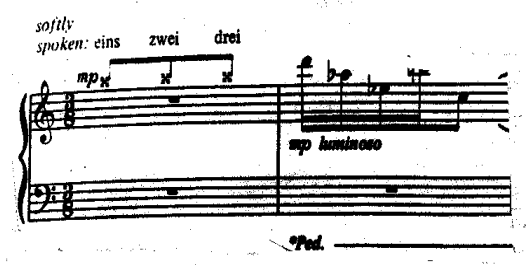

The waltzes in this collection were all written between 1976 and 1978, but most of them appeared in 1977. They show various formal characteristics, complicated rhythms and time signatures, highly specific score indications; most are non-tonal as well. They range in technical demands from intermediate level to moderately difficult. These pieces show that plenty of excitement and dash still exist in this old dance form.

\section{Morton Gould's "Ghost Waltzes"}

The "Ghost Waltzes" were composed in 1991 and published in 1992. They were commissioned for the Ninth Van Cliburn International Piano Competition (1993). Morton Gould describes the "Ghost Waltzes" as follows:

The first musical sounds I heard in my early years came from my parents' player piano. The music on those piano rolls reflected the taste of that period, with a preponderance of waltzes of all kinds--Viennese, Russian, American, Chopin, Strauss, etc. This piece, therefore, is a distillation of these dance forms in three-quarter time-- nostalgic, poignant, assertive, reflective, brash, sentimental, celebrative, elegiac. It is a fantasy collage of my waltz memories filtered through time, with haunting "pianola" intertwining throughout. I thought it appropriate for the Van Cliburn International Piano Competition to attempt a virtuosic piece that enables the performer to rhapsodize these many constrasting textures and moods that are unique to the waltz. ${ }^{64}$

The "Ghost Waltzes" divide into ten sections. ${ }^{65}$ 
Section 1: mm. 1-49

This serves as an introduction and creates a rather vague atmosphere.

Section 2: mm. 50-63

Here a single melody with accompaniment appears; Gould indicates a slightly slower tempo for this section.

Example 3-48. Morton Gould "Ghost Waltzes," mm. 51-53

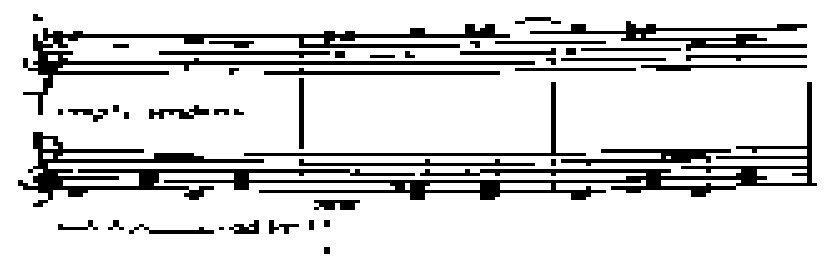

Section 3: mm. 97-120

This entire section is influenced by blues style. We see rolling accompaniment figures in m. 98, m. 100, and mm. 102-103, and consecutive tremolos in mm. 104-107. Example 3-49. Morton Gould "Ghost Waltzes," m. 97 and mm. 104-107

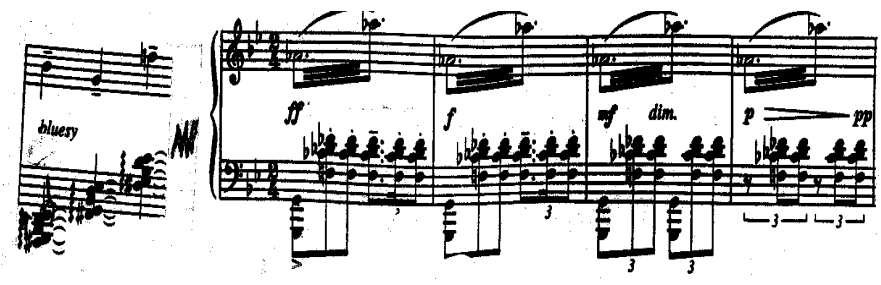

Section 4: mm. 121-161

Here the tempo changes from Piú mosso (mm. 104-120) to Presto (mm. 121-161), and a jazzy character prevails in this section.

Example 3-50. Morton Gould "Ghost Waltzes," mm. 121-122

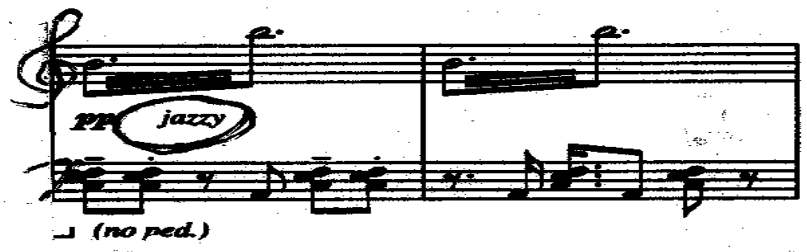


Section 5: mm. 162-202

Eighth notes are the prevailing rhythmic unit of this section.

Example 3-51. Morton Gould "Ghost Waltzes," mm. 162-163

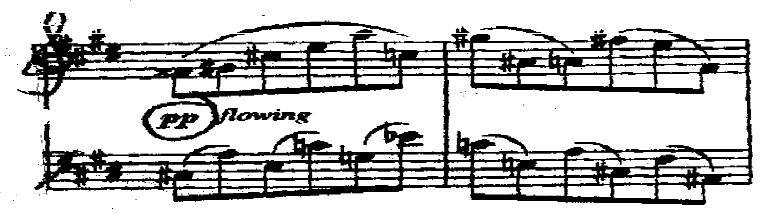

Section 6: mm. 203-248

As in Section 5, eighth notes are the dominant rhythmic figures. Also, there are some changing meters (two-four, three-four, and five-eight) and key signatures as well. Section 7: mm. 249-299

The rhythmic and melodic motives in $\mathrm{mm}$. 270-279 derive from $\mathrm{mm}$. 68-75 in Section 2.

Example 3-52. Morton Gould "Ghost Waltzes," mm. 270-271 and mm. 68-69

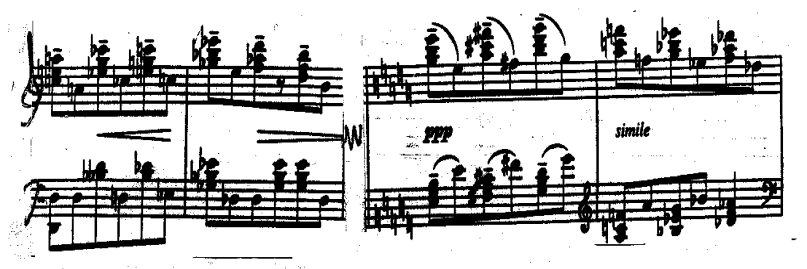

1

Section 8: mm. 300-351

Like the beginning of section 2 , this section starts with conventional waltz style, including graceful melody and simple accompaniment.

Example 3-53. Morton Gould "Ghost Waltzes," mm. 300-301

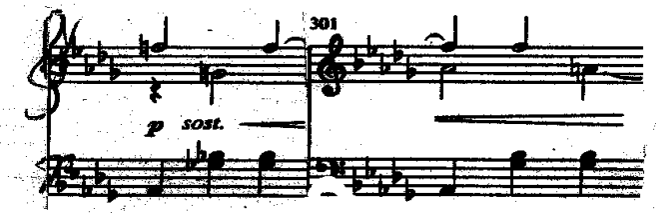


Section 9: mm. 352-426

Section 9 provides the climax of the entire piece. It starts with massive chords marked fortississimo. In $\mathrm{m}$. 366, the subito piano produces a dramatic contrast to the previous fortississimo.

Example 3-54. Morton Gould "Ghost Waltzes," mm. 352-353 and mm. 366-367

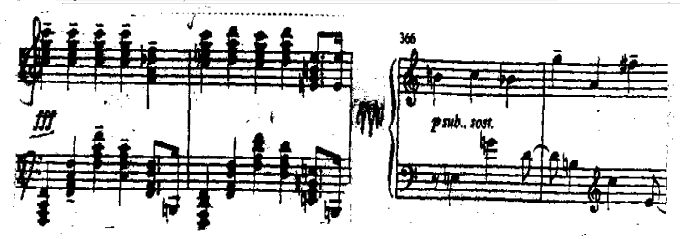

Section 10: mm. 427-457

At the end of the "Ghost Waltzes," Gould recalls the introductory material. Section 10 is an approximate retrograde of the beginning (mm. 1-49) and A-major triads appear in both the first measure and the last measure of the work.

Example 3-55. Morton Gould "Ghost Waltzes," m. 1 and m. 459

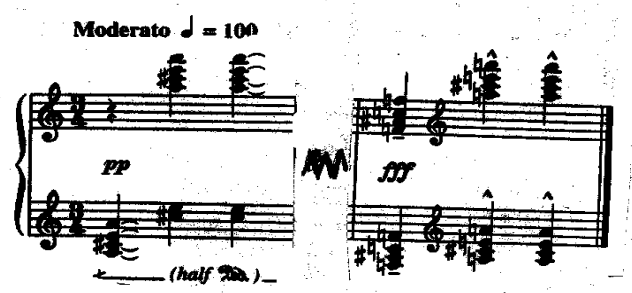

In the "Ghost Waltzes," meters, key signatures, rhythms and tempos change frequently. The meter is mainly three-four, but three-eight, five-eight, two-four, and fivefour also occur. In mm. 80-84, the meters change in every bar. Example 3-56. Morton Gould "Ghost Waltzes," mm. 80-84

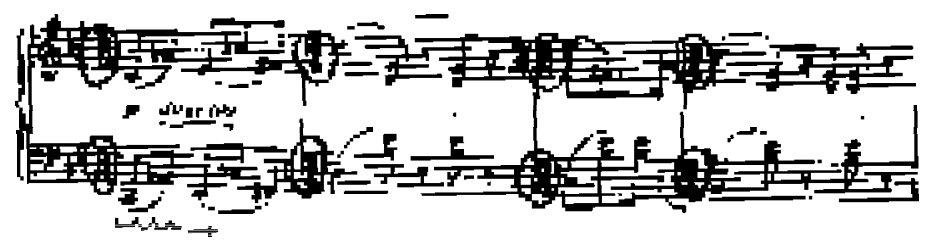


Also, in mm. 80-84, due to the changing meters, we hear changes in speed between fast and slow.

In the "Ghost Waltzes," the key signatures change frequently. Gould uses key signatures ranging from one flat to six flats as well as several different sharp keys.

At the beginning of the piece, we see rhythmic ostinatos of sixteenth-note arpeggios (mm. 28-40) and triplets (mm. 17-27 and mm. 41-44). Five-against-four and four-againstthree rhythms appear in mm. 8-11. Consistent dotted rhythms occur in mm. 134-151. We see complex irregular groupings of eight notes in mm. 162-164 and Gould writes syncopated rhythms in m. 203, mm. 211- 212, and in m. 386.

As Gould mentions in his own description cited above, various melodic and rhythmic characters appear in each section and these different characters of the sectional waltzes come together to create one unified work.

This chapter concludes with a brief listing of other twentieth-century piano waltzes in France, Germany, Russia, Spain, Great Britain and Mexico.

\section{France}

Eric Satie (1866-1925)

Valses distinguées d'un précieux dégoûté (Distinguished Waltzes

of a Disgusted Dandy), a humorous, satirical work that contains some bitonality. ${ }^{66}$

Claude Debussy (1862-1918)

La plus que lente (1910)

Originally written for piano and then orchestrated. This charming waltz could actually be danced and Debussy used a tune very popular in Paris at that time, "La valse lente." ${ }^{67}$ 


\section{Germany}

Paul Hindemith (1895-1963)

Sieben Walzer, Op. 6 (1916) for piano duet.

Four-hand music in the old Viennese tradition. ${ }^{68}$

Arnold Schönberg (1874-1951)

Fünf Klavierstücke (Five Pieces), Op. 23 (1923)

No. 5 is a waltz written with serial technique. The twelve-note row note is:

c-sharp, a, b, g, a-flat, g-flat, d, e, e-flat, c, and f. ${ }^{69}$

\section{Russia}

Alexander Scriabin (1872-1915)

Two waltzes, in G-sharp and D-flat

"Valse," Op. 38, (1903)

Igor Stravinsky (1882-1971)

A set of five characteristic pieces for piano duet, including one waltz. ${ }^{71}$

\section{Spain}

Enrique Granados (1867-1916)

"Valse de Concert"

"Carezza" (Spanish Waltz)

"Valses poéticos" 
These three waltzes reflect Spanish nationalism. ${ }^{72}$

\section{Great Britain}

Frederick Delius (1862-1934)

Valses bourgeoises for piano duet (1971)

This work is known for its parody of Strauss's waltzes. ${ }^{73}$

Benjamin Britten (1913-1976)

"Waltzes," Op.3 (1923-1925) $)^{74}$

\section{Mexico}

Carlos Chávez (1899-1978)

"Waltzes" (1919-1921) ${ }^{75}$

This section has explored various compositional styles in twentieth-century waltzes, considering formal structures, melodies, rhythms, harmonies, key changes and pedal marks.

Formal structures in twentieth-century waltzes include not only the traditional ABA architecture, but also various types of sectional waltzes. For example, Bartok's "Valse" (No. 14 from Bagatelles) and Morton Gould's "Ghost Waltzes" reveal multiple sections, while Ravel's Valses nobles et sentimentales and Prokofiev's "Valse" movement from Sonata No. 6, Op. 82 reflect ABA forms. Serial techniques occur in Schönberg's "Waltz" (No. 5 from the Klavierstücke, Op. 23) and we also see minimalism (Glass) and chance operations (John Cage).

The melodies of Ravel's Valses nobles et sentimentales reveal a light and elegant, danceable character. Prokofiev's third movement of the Sonata No. 6, Op. 82, 
demonstrates nocturne-like, lyrical melodies. By contrast with these two waltzes, Bartok's 'Valse" is far less graceful in its melodies, perhaps because the subject (forced to death) of this waltz suggested a sardonic treatment.

In Schönberg's Walzer, the twelve-tone row determines the melodies. The row appears four times: mm. 1-4 (treble clef), mm. 17-18 (treble clef), mm. 29-31 (both bass and treble) and mm. 89-90 (treble clef).

In Shostakovitch's "Waltz" (No. 15 from Twenty-Four Preludes, Op. 34), staccato melody in the bass dominates the piece; thus, the accompaniment appears in the treble clef.

In Gould's "Ghost Waltzes," various types of melodies occur in the multiple sections, sometimes including traditional waltz textures with simple melody and accompaniment.

The varieties of rhythms are the most striking features in twentieth-century waltzes. Ostinato patterns appear in Bartók's "Valse" and in the introduction of Gould's "Ghost Waltzes." The "Ghost Waltzes" demonstrate blues and jazz rhythms and we also find fouragainst-three and four-against-five rhythms in m. 8. In Prokofiev's "Valse," we see a homo-rhythmic treatment in the main theme of section A. Also, consistent rhythmic patterns appear in No. 4 of Ravel's Valses nobles et sentimentales.

In No. 5 from Schönberg's Klavierstücke Op. 23, we see very complex rhythms that change quickly from measure to measure.

Compared to nineteenth-century examples, twentieth-century waltzes often use much more daring harmonies or dispense with tonality altogether. Sometimes twentiethcentury composers use traditional tonal functions, but mix different harmonic languages. Examples of this appear in Gould's "Ghost Waltzes." Even though Gould employed many 
non-chord tones in key places, the "Ghost Waltzes" reveal a fairly traditional concept of tonality, using the same diatonic chords at the beginning and the ending. In the early twentieth century, Ravel used bitonality in the B section of Valse No. 7 and ninth chords in Valse No. 1.

In the twentieth century, changing keys, meters, and dynamics occur much more frequently than in nineteenth-century waltzes. Examples include Morton's Gould's "Ghost Waltzes," several pieces in Waltzes by 25 Contemporary Composers, Schönberg's Walzer, Op. 23, No. 5, and Bartók’s "Waltz" from Bagatelles, Op. 6.

Another important feature of twentieth-century waltzes is the use of specific pedal marks. Many twentieth-century composers indicated pedal marks very exactly in their music, including "tremolo" and "flutter" pedaling, and requiring the use of the sostenuto pedal. 


\section{Summary}

Since the appearance of the waltz in the early eighteenth century, many composers have been writing waltzes for various purposes. The waltz became popular throughout Europe in the early nineteenth century.

In solo piano music of the nineteenth century, Schubert, Weber, Chopin, Brahms and Liszt were the major composers of waltzes. In the earliest waltzes, we typically find two repeated eight-measure phrases, with simple melody and accompaniment. Schubert produced many dance pieces of this sort under various titles, primarily intended for actual dancing or entertainment at home.

Schubert's waltzes are usually quite short (often 16 bars long) and technically easy for the player. They served as primary sources for later nineteenth-century and twentiethcentury composers. Several composers, including Franz Liszt, transcribed some of Schubert's waltzes, giving them more virtuosic treatment.

Weber's "Invitation to the Dance" is a programmatic work and its formal structure (introduction, series of dances, and coda) significantly influenced later nineteenth-century composers. Perhaps in the tradition of Schubert's remote modulations, Weber employed modulation from D-flat to $\mathrm{C}$ major as a prominent feature.

Brahms' Waltzes Op. 39 seem more strongly influenced by Schubert's waltzes in terms of their formal structure, with the characteristic swaying of the Viennese waltz and little attempt to extend the form of the waltz. However, these pieces reveal the joyful mood of the dance and each waltz conveys distinctive melody, rhythm and accompaniment styles. 
Compared to the waltzes of Schubert and Brahms, most of Chopin's waltzes are not intended for actual dancing, but rather as stylized salon waltzes for concert performance. Within the ABA structure of Chopin's waltzes, the B section is also typically much longer and more relaxed in melody, rhythm and mood than the A sections.

Liszt's First Mephisto Waltz demands a truly virtuosic pianistic technique. This waltz was based on the second of two episodes in the poem Faust by Lenau. Unlike the gentle elegance of most waltzes by other nineteenth-century composers, Liszt dealt with a demonic idea in his First Mephisto Waltz. The sectional formal structures of the First Mephisto Waltz also differ from previous piano waltzes in the nineteenth century, with the exception of Weber's "Invitation to the Dance." Liszt's use of chromatic passages, disguise of the tonal functions, and frequently changing tempos and meters in the First Mephisto Waltz extended a strong influence on later composers.

When we turn to the twentieth century, we see that composers continued to expand the traditional concept of the waltz. As in Liszt's First Mephisto Waltz, Bartók's waltz was based on a folklore tale. The melody of Bartók's waltz is deliberately biting, rather than graceful.

By contrast, both Prokofiev's and Ravel's waltzes followed more traditional styles, such as ABA form and a feeling of swaying melody and rhythm.

Ravel's Valses nobles et sentimentales display the influence of Chopin's waltzes regarding the three-against-two rhythms and the ABA structure.

Ravel's last waltz, Épilogue, reflects impressionistic blurring of sound. Also, the 
Épilogue is a cyclic form which recalls all of the preceding waltzes, except Waltz No. 5.

In the waltzes which appeared after the 1960s, we rarely find the traditional graceful melody and gently swaying rhythms. Instead, we see complex rhythms and irregular meters. In John Cage's "49 Waltzes for the Five Boroughs" we see chance operations and in Philip Glass's 'Modern Love Waltz" we find minimalism."

Morton Gould's "Ghost Waltzes" reveal various characters, mixing the traditional concept of the waltz with modern ideas, including influences of jazz and blues.

Between Bartók and Gould we see a few common features. First, both waltzes are in sectional structures; second, the beginning thematic material reappears at the end; and third, Bartók and Gould used ostinatos (repeated rhythmic patterns) in prominent ways.

In the twentieth century, the waltz continues to evolve away from simple ballroom pieces toward highly stylized expression. Although some of neo-classical Ravel's Valses nobles et sentimentales could actually be danced, most of the waltzes in the twentieth century show much less traditional writing styles.

It is surely true that the waltz is still loved by many music devotees, musicians and composers because of its uplifting rhythms and the attractive melodies of many nineteenthcentury favorites. However, the waltz has been greatly developed and expanded by stylistic innovations. For the foreseeable future, we can expect that many composers will make further artistic explorations into new possibilities for this delightful traditional dance. 


\section{Endnotes}

1. Andrew Lamb. "Waltz:in the book A Description of the Concert Method of Waltzing (published in 1816)." an cited in Grove Dictionary of and Musicians, (Stanley Sadie ed., 1980), XX, p. 203.

2. Paul Nettl. The Story of Dance Music. (New York: Philosophical Library, 1947), pp. 256-257.

3. Egon Gartenberg. Johann Strauss, (London: The Pennsylvania State University Press, 1974), p. 35 .

4. Nettl, The Story of Dance Music, p. 257

5. Andrew Lamb. "Waltz" in Grove's Dictionary of Music and Musicians, (Stanley Sadie ed., 1980), XX, p. 200.

6. Nettl, The Story of Dance Music, p. 254.

7. Peter Grammond. "Waltz," in The New Oxford Companion to Music, p. 1966.

8. Nettl, The Story of Dance Music, pp. 257-258.

9. F.E. Kirby. Music for Piano, (Portland, Oregon: Amadeus Press, 1997), pp. 130-131.

10. Maurice Brown. Essay on Schubert, (New York: St. Martin's Press, 1965), pp. 292-293.

11. Grove's, "Lanner," X, p. 456.

12. Denis Arnold, ed. "Strauss I," The New Oxford Companion to Music, p. 626.

13. Grove's, "Lanner," X, p. 456.

14. Denis Arnold, ed. "Strauss II," The New Oxford Companion to Music, p. 626. 
15. Grove's, "Strauss II," XVII, p. 210.

16. Lynn Rice-See. "Schubert's Wonderful Dances," Clavier, January 1997, 14.

17. Ibid., p. 15.

18. Ibid., p. 14

19. Jonn Warrack. Carl Maria von Weber, (New York: The Macmillan Company, 1968), pp. 191-191.

20. Andrew Lamb. "Waltz" in Grove's Dictionary of Music and Musicians, (Stanley Sadie ed., 1980) XX, p. 203.

21. Don Michael Randel. The New Harvard Dictionary of Music, (London: The Belknap Press of Harvard University Press, Cambridge, 1986), p. 931.

22. Warrack, Carl Maria von Weber, p. 191.

23. Adam Harasowski. "An Overview of Chopin's Piano Music," Piano Quarterly, $29^{\text {th }}$

Year/Spring 1981, p. 30.

24. Ursula Klein, "Frédéric Chopin 17 Waltzes," (MHS 512304 T)

25. Kirby, Music for Piano, p. 195.

26. Ibid., p. 195.

27. Frédéric Chopin, Waltzes, (Dover Publication, 1998)

28. Henry Levine, "Brahms Simplified Brahms" Clavier, February 1974, p. 14.

29. Michael Musgrave, The Music of Brahms, (Oxford: Clarendon Press, 1994), p. 63.

30. Edwin Evans, PianoForte Works of Johannes Brahms, (London: The New Temple Press), p. 171.

31. Kirby, Music for Piano, p. 242.

32. Ibid., p. 225.

33. Mary Angela Hunt, "Franz Liszt: The Mephisto Waltzes" (Ph. D. Dissertation, The University of Wisconsin-Madison, 1979), p. 17. 
34. Sacheverell Sitzwell, Liszt, (Boston and New York: Houghton Mifflin Company, 1934), p. 248.

35. Mary Angela Hunt, "Franz Liszt: The Mephisto Waltzes" (Ph. D. Dissertation, The University of Wisconsin-Madison, 1979), pp. 26-30.

36. Kirby, Music for Piano, p. 209.

37. William Lloyd Adams Jr. "A History of Concert Waltzes for Piano." (D. M. A. Dissertation. North Texas State University, 1978), p. 38.

38. Stewart Gordon, A History of Keyboard Literature, (New York: Schirmer Book, 1966), p. 319.

39. Kirby, Music for Piano, p. 169.

40. Ibid., p. 169.

41. Ibid., pp. 251-252.

42. Ibid., pp. 253-255.

43. Grove's "Saint-Saëns" XVI, p. 406.

44. Kirby, Music for Piano, p. 257.

45. Ibid., p. 258.

46. Ibid., p. 265.

47. Clarence Hamilton, Piano Music, (Boston: Oliver Diston Company, 1925), p. 175.

48. John Gillespie, Five Centuries of Keyboard Music, (New York: Dover Publication, 1965), p. 283.

49. Waltzes by 25 Contemporary Composers (New York: C. F. Peters Corporation, 1978)

50. Don Michael Randel, ed. The New Harvard Dictionary of Music, (London: The Belknap Press of Harvard University Press Cambridge, 1986), p. 65.

51. John Purswell, "Bartók’s Early Music," Clavier, October 1981, 23. 
52. Ibid., p. 23.

53. Jeffrey Shumway, "A Comparative Study of Representative Bagatelles for the Piano Since Beethoven," (D. M. A. Dissertation, Indiana University, (1981), p. 52.

54. Stewart Gordon, A History of Keyboard Literature, (New York: Schirmer Books, 1996), p. 441

55. Rebecca Gena Matin, "The Nine Piano Sonatas of Sergei Prokofiev" (D.M. A. Dissertation. The University of Kentucky, 1982), p. 41.

56. Stephen C. E. Fiess, The Piano Works of Sergei prokofiev, (London: The Scarecrow press, 1981), p. 12.

57. Ibid., p. 159.

58. Rollo Myers, Ravel Life and Works, (Gerald Duckworth, 1960), p. 170.

59. Ibid., pp. 170-171.

60. Ibid., pp. 168-170.

61. Lynn Rice-See. "Schubert's Wonderful Dances," Clavier, 16

62. Gordon, A History of Keyboard Literature, p. 398.

63. Waltzes by 25 Contemporary Composers, (New York: C. F. Peters Corporation, 1978)

64. Morton Gould, Ghost Waltzes, (G. Schirmer, Inc., 1992) (preface)

65. Based on suggestion given by Dr. James Miltenberger to his piano student, Eun-Suk Jung.

66. Kirby, Music for Piano, p. 289.

67. Robert Schmitz, Claude Debussy, (New York: Dover Publications, 1950), p. 127.

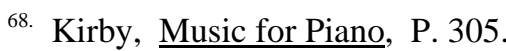

69. Willi Reich, Schönberg, a Critical Biography, (New York; Praeger Publishers, 1971), p. 139.

70. Kirby, Music for Piano, p. 320.

71. Ibid., p. 324. 
72. Ibid., p. 332.

73. Ibid., p. 339.

74. Ibid., p. 340.

75. Ibid., p. 357. 


\section{Bibliography}

Brown, Maurice. Essays on Schubert. London and New York: Macmillan, St. Martin's Press, 1965

Daverio, John. Robert Schumann: Herald of a New Poetic Age. New York: Oxford University Press, 1997

Evans, Edwin. PianoForte Works of Johannes Brahms. Great Britain: The Temple Press

Fiess, Stephen C. E. The Piano Works of Serge Prokofiev. Metuchen, N. J., \& London: The Scarecrow Press, 1994

Ewen, David. $20^{\text {th }}$ Century Music. Englewood Cliffs: Prentice-Hall. Inc. N. J., 1959

Gartenberg, Egon. Johann Strauss. University Park and London: The Pennsylvania State University Press, 1974

Gillespie, John. Five Centuries of Keyboard Music. New York: Dover Publications, Inc., 1965

Gordon, Stewart. A History of Keyboard Literature. New York: Schirmer Books, 1996

Hutcheson, Ernest. The Literature of the Piano. New York: Alfred A. Knopf, 1964

Kirby, F. E. Music For Piano. Amadeus Press: Portland, Oregon: Amadeus Press, 1997

Manuel, Robert. Twentieth Century Music. New York and London: W.W. Norton and Company, 1991

Maxwell, Carolyn and Devan, William ed. Schumann. Colorado: Maxwell Music Evaluation Books, 1984

Meyers, Rollo H. Ravel Life and Works. London: Gerald Duckworth and Co. Ltd, 1960

Musgrave, Michael. The Music of Brahms. Oxford: Clarendon Press, 1994

Nestyev, Israel V. Sergei Prokofiev. New York: Alfred A. Knopf, 1946

Nestyev, Israel V. Sergei Prokofiev. Stanford, California: Stanford University Press, 1960 
Nettle, Paul. The Story of Dance Music. New York: Philosophical Library, 1947

Reich, Willi. Schoenberg, a Critical Biography. New York, Washington: Praeger Publishers, 1971

Sachs, Curt. World History of the Dance. New York: W.W. Norton and Co., Inc., 1937 Trans. By Bessie Schoenberg

Schmitz, Robert. Claude Debussy. New York: Dover Publications, Inc., 1950

Sitzwell, Sacheverell. Liszt. Boston and New York: Houghton Miffin Company, 1934

Seroff, Victor. Maurice Ravel. New York: Henry Holt and Company, 1953

Stevens, Halsey. The Life and Music of Bela Bartok. Oxford: Clarendon Press, 1993

Warrack, John. Carl Maria von Weber. New York: The Macmillan Company, 1968

\section{Reference Works}

Arnold, Denis, ed. The New Oxford Companion to Music. Oxford and New York: Oxford University Press, 1983

Randel, Don Michael, ed. The New Harvard Dictionary of Music. Cambridge, Massachusetts, and London: The Belknap Press of Harvard University Press, 1986

Stanley, Sadie, ed. The New Grove Dictionary of Music and Musician. London: Macmillan Publishers Limited, 1980

Thompson, Kenneth. A Dictionary of Twentieth Century Composers (1911-1971). London: Farber and Farber, 1973

Westrup, J. A. and Harrison, F.Ll. The New College Encyclopedia of Music. New York: W.W. Norton \& Company, Inc. , 1976 


\section{Periodicals}

Chaikin, Lawrence. “The Prokofieff Sonatas: A Psycho Graph,” The Piano Quarterly $22^{\text {nd }}$ Year/Summer 1974, 8-19

Dubal, David. "Robert Schumann's Piano Music," The Piano Quarterly, 33 ${ }^{\text {rd }}$ Year/Fall 1985, 59-63

Dumm, Robert. "Enjoying the Paradoxes of Maurice Ravel," Clavier, October 1995, 28-31

Elder, Dean. "Memories of Ravel," Clavier, October, 1975, 17-20

Elder, Dean. "Perlemuter on Ravel," Clavier, March 1982, 18-19

Gruber, Albin. "Some Viewpoints on Brahms," Clavier, February 1974, 9-13

Hughes, Walden. "Franz Schubert's Wonderful Dances," Clavier, January 1997, 10-13

Levine, Henry. "Brahms Simplifies Brahms," Clavier, February 1974, 14-20

Orenstein, Arbie. "Maurice Ravel's Creative Process," The Musical Quarterly, October 1967, 467-481

ParkerMont, Carol. "Chopin Waltz Manuscript," Clavier, October 1979, 8-13

Purswell, Joan. “Bartok’s Early Music,” Clavier, October 1981, 23-24

Rice See, Lynn. “Schubert's Wonderful Dances,” Clavier, January 1997, 14-17

Rosen, Charles. "Where Ravel Ends and Debussy Begins," Clavier, December 1967, 14-17

Sevilla, Jean-Paul. “Maurice Ravel,” Clavier, October 1975, 13-16 


\section{Dissertations}

Adams, William Lloyd, Jr. "A History of Concert Waltzes for Piano.” D. M. A. Dissertation. North Texas State University, 1978

Angela, Mary Hunt. "Franz Liszt: The Mephisto Waltz.” Ph. D. Dissertation. The University of Wisconsin-Madison, 1979

Brodbeck, David Lee. "Brahms as Editor and Composer." Ph. D. Dissertation. University of Pennsylvania, 1984

Dubbiosi, Stelio. “The Piano Music of Maurice Ravel.” Ph. D. Dissertation. New York University, 1967

Matin, Rebecca Gena. "The Nine Piano Sonatas of Sergei Prokofiev.” D. M. A. Dissertation. The University of Kentucky, 1982

McCrae, Elizabeth. "Ravel's Valses nobles et sentimentales.” D. M. A. Dissertation. Boston University, 1974

Pepin, M. Natalie. "Dance and Jazz Elements in the Piano Music of Maurice Ravel."

D. M. A. Dissertation. Boston University, 1972

Reynold, Sylvia R. "The Lyric Pieces of Edvard Grieg." D. M. A. Dissertation. The University of Kansas, 1979

Shumway, Jeffrey, "A Comparative Study of Representative Bagatelles for the Piano Since Beethoven.” D. M. A. Dissertation. Indiana University, 1981 